REVIEW ARTICLE

\title{
Recent Advances in Pathophysiology of Traumatic Brain Injury
}

\author{
Parmeet Kaur and Saurabh Sharma* \\ Department of Pharmacology, I.S.F College of Pharmacy, Moga-142001, Punjab, India
}

A R T I C L E H I S T O R Y
Received: February 20, 2017
Revised: March 22, 2017
Accepted: May 08, 2017
DOI:
$10.2174 / 1570159 X 15666170613083606$

$10.2174 / 1570159 X 15666170613083606$

\begin{abstract}
Background: Traumatic brain injury (TBI) constitutes the primary reason for mortality and morbidity in persons worldwide below 45 years of age. 1.7 million Traumatic events occur yearly in the United States alone, considering for 50,000 deaths. In severe traumatic brain injury sufferers, a considerable achievement attained in treating short-term consequences; but till date, huge failures are occurring in researcher's capability to render severe traumatic brain injury sufferers to an elevated degree of performing.
\end{abstract}

Methods: Initial damage force results in Primary brain injury, causing tissue destruction and distortion in the early post-injury period. These secondary injuries from TBI cause changes in cell performance and dissemination of trauma via activities like free-radical generation, depolarization, and formation of edema, excitotoxicity, and disruption of blood brain barrier, calcium homeostasis, and intracranial hematoma. The expectation for developing effect in TBI sufferers is the best knowledge of these activities and enhancement of remedies that restrict secondary brain damage.

Results: The focal point of this study is on knowing the complex outburst of secondary impairments and studying the pathophysiology of TBI which provides alternative treatment benefits.

Conclusion: While injured persons demonstrate dissimilar levels of harm and every case is novel with specific recovery profiles, this article strengthens the recent pathophysiological sight of TBI mainly attention on oxidative stress, excitotoxicity, cerebral oxygenation and cerebral blood flow $(\mathrm{CBF})$, development of edema, and inflammatory activities. For initial research acknowledgment of these recurring factors could permit clarification of possible beneficial targets.

Keywords: Traumatic brain injury, secondary injury, primary brain injury, oxidative stress, excitotoxicity, inflammation.

\section{INTRODUCTION}

Traumatic brain injury (TBI) is the popular reason of injuries and disabilities and is major health concern among youngsters worldwide [1]. TBI is defined as a nondegenerative, noncongenital injury to the brain occurring via an extraneous physical strength that may result in impaired or changed level of consciousness, leading to permanent or temporary disabilities of cognitive or physical functioning. In the United States, TBI is a contributing factor to approx. $40 \%$ of all injury-related deaths. Reports from Centers for Disease Control (CDC) show approx. 1.72 million people in the United States as facing TBI and 275,000 are hospitalized annually [2, 3]. These experiences are accountable for 50,000 deaths, leaving 70,000 Americans with long-term impairments per year and 5.3 million people in the U.S. exist with such disabilities creating a remarkable emotional and socioeconomic burden on the society and families [4]. TBI

*Address correspondence to this author at the Department of Pharmacology, I.S.F College of Pharmacy, Moga-142001, Punjab, India; Tel: 01636324200, 324201; Fax: 01636-239515; E-mail: ssm.research@gmail.com usually results from a violent blow or jolt to the head from a blunt or penetrating object into the skull such as a bullet or a sharp piece object [5]. Studies show that TBI is a frequent injury in sports victims, motor vehicle crashes, and these victims often have short and long-term emotional, cognitive, behavioral and physical disabilities [6, 7]. Following TBI, neurological deficits, behavioral alterations, and cognitive decline commonly occur and impose a dramatic impact on patients, which has become a significant public health problem. Mechanical insult causes alterations in cerebral metabolism and blood flow that cause cellular dysfunction and risk to secondary injuries such as hypoxia, hypotension, cognitive impairment and seizures [8]. Altered metabolic function in cells may initiate glutamate-induced excitotoxicity and neuronal cell death. Alteration in calcium homeostasis leads to increase in the reactive oxygen species and generation of inflammatory mediators that lead to the cell death [9]. Even after an extensive work on brain trauma, there are no reliable neuroprotective agents for the treatment of patients suffering from TBI till date. Motor vehicle fall, sporting or leisure, workplace injuries, accidents, assaults, blasts and military combats are a major cause of TBI in developing nations, 
making it need of the hour for novel therapeutic interventions.

\section{PATHOPHYSIOLOGY}

TBI results from a violent collision, acceleration - deceleration and rotational movement of the brain that leads to distorted mental functioning [9]. For learning features of primary and secondary brain injury, TBI animal models are mainly used. Primary injury donates to the first collision that promotes the brain to be knocked inside the skull. While damage results from ischemia, subsequent swelling, infection and intracranial hematoma are a secondary injury [10]. The principal mechanisms of TBI have been studied as:

- After TBI, the cerebral injury is manifested by extreme tissue harm and diminished metabolism and CBF regulation which is thought to be the first step in the pathophysiology of TBI [11]. Thus, these produce an ischemia-like condition that results in anaerobic glycolysis owing to gathering of lactic acid and elevated membrane permeability results in edema formation. Insufficiency of anaerobic metabolism to sustain cellular energy levels causes depletion of ATP-stores and energy-dependent membrane ion pumps stoppage [8].
- Terminal membrane depolarization together with the extreme discharge of glutamate and aspartate (i.e. excitatory neurotransmitters) is manifested as next step of the pathophysiological flow [12].

- These processes activate proteases, lipid peroxidases, and phospholipases which sequentially increase the intracellular accumulation of oxygen radicals and free fatty acids.

- Collectively, all these result in membrane cellular and vascular system destruction and ultimately apoptosis (programmed cell death) or necrosis [8].

\section{PRIMARY INJURY}

The primary injury represents the focal (e.g., intracranial hematomas, skull fractures, lacerations, contusions and penetrating wounds) and diffuses mechanical harm imposed on the brain at the moment of the collision [13]. The primary insult originating TBI is determined to occur in short span i.e. 100 milliseconds, although it causes damage to the cranial vault and furthermore destroys cerebrovascular systems by distressing fractured bone inside the brain [14]. All these promote shearing of the blood vessel and axons which are generated by the injury (Fig. 1). Intracerebral bleeding leads

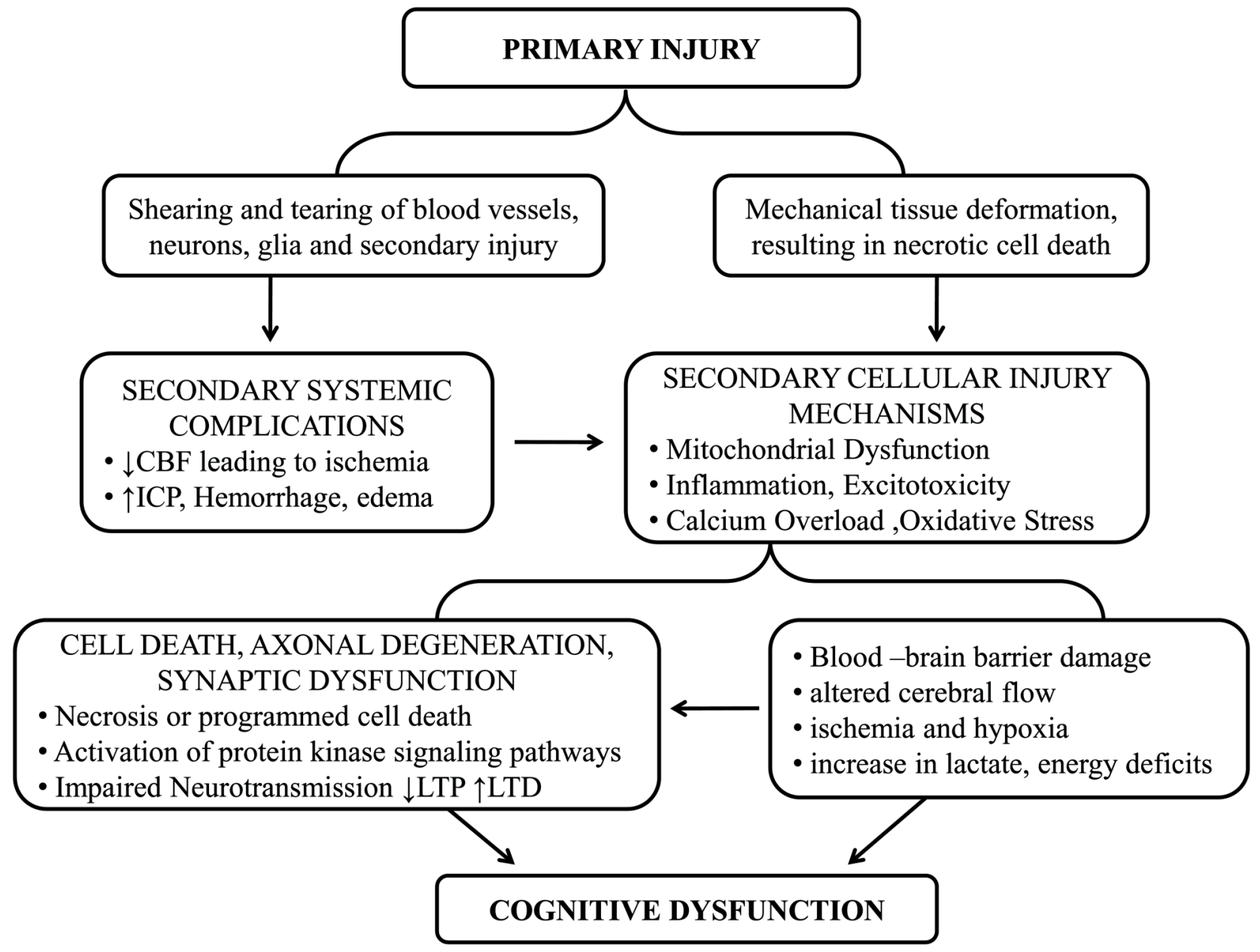

Fig. (1). Pathophysiology of Primary Brain Injury. 
to hemorrhage and tearing of blood vessels inside brain parenchyma generating mass lesions [13].

\section{TYPES OF PRIMARY INJURIES}

\subsection{Intracranial Hematoma}

A frequent cause of damage and destruction following primary injury is an Intracranial hemorrhage. Different types of intracranial hematoma can happen, containing the following:

- $\quad$ Bleeding between the dura and skull area involves Epidural hematoma which mainly results from insult loading into the skull through related laceration of the dural veins or arteries, usually via fractured bones and occasionally by diploic veins within skull's marrow. A common cause of epidural hematoma is the break of the middle meningeal artery because of fractured temporal bone [15]. It is an arterial bleeding through a speedy rise in pressure. When hematoma results from laceration of an artery, instant neurologic deterioration occurs from blood collection and is dangerous in the acute stages following TBI [16].

- A Subdural hematoma produces in the subdural space from ruptured veins and usually takes place in severe TBI victims with impairments to the pial artery or cortical veins. The related rate of mortality is elevated, i.e. $60-80 \%$ approximately. The flow of blood is limited to the region within the arachnoid membrane and the dura in patients with a subdural hematoma [17]. Subdural hematomas do not develop as rapid as epidural hemorrhage but also proceed to mass lesions resulting in mortality and dysfunctioning [18].

- Intracerebral hemorrhages refer to bleeding within the brain itself; these mostly occur inside the cerebral parenchyma inferior to lacerations or to brain contusion, with a damage to superior, deeper cerebral vessels happening through a broad cortical contusion [19].

- Subarachnoid hemorrhages generally take place in many cases of TBI and if blood components hinder the arachnoid villi then hemorrhage may result in communicating the type of hydrocephalus or on an instance of the noncommunicating type of hydrocephalus, inferior to the blood clot blocking the third or fourth ventricles [17].

\subsection{Skull Fractures}

- In youngsters, $10 \%-30 \%$ of head damages lead to skull fractures [19]. Fractures are described as nondepressed or depressed, based on either or not the inward displacement of fragments occurs. A simple fracture is known in which there is 1 bone fragment; when there more than 2 bone fragments, then compound fractures occur [16].

- Skull fractures may be related to cranial nerve damage, hematoma, and increased brain injury. Approximately $4 \%$ of all head injuries comprise skull base fractures [20]. Most of these fractures (90\%) are secondary to closed head trauma; the remaining are caused by penetrating trauma [21].

- Cranial nerve injuries can result from skull fractures which are particularly at the base of the skull. In TBI, the generally damaged cranial nerve is the facial nerve, resulting in paralysis of facial muscles [19]. Skull fractures can give rise to leaks of cerebrospinal fluid (CFS) by damaging the membranes that cover the brain. A subdural hygroma may generate from Intracranial CFS leaks [17]. Extracranial CFS discharge via the ears and nose permits bacteria and air to go into the skull, thereby producing pneumocephalus or infections like brain abscess or meningitis [16, 19].

\subsection{Coup and Contrecoup Contusions}

A contusion can happen in the nonexistence of skull fractures as a result of movement of the brain back and forth in the boundaries of the skull. This is known as 'Coup contrecoup mechanisms' [20]. A contusion is a discrete region of inflamed brain tissue, combined with blood coming out from broken blood vessels [22]. Cerebral contusion results from the mixture of vascular \& tissue harm [23]. Contrecoup contusions are similar to coup contusions but are situated on the opposite side of the direct insult [16]. If the resulting injury is the coup or contrecoup, it is regulated by the amount of energy degenerated at the position of direct insult. Most of the energy of insult from a bigger object causes a smaller amount of injury at the collision site, owing to energy degenerated at the starting or finish of the head movement, resulting in a contrecoup contusion [24]. However, the insult from a hard, smaller object inclined to distribute at the insult position, causes coup contusion [25]. Contusions are usually originated in the inferior and poles of frontal lobes, the lateral and secondary aspects of the temporal lobes and the cortex over and under the operculum of the Sylvian fissures [26]. In addition, diffuse axonal injury (DAI) is originated from the rotational movements of the brain [27]. The victims with DAI usually may be unaware of minute radiological results on CT scanning, findings from microscopic destruction to single nerve cells (neurons) and breakdown of links amongst nerve cells [22]. Because of the fast lengthening of the axons, the cytoskeleton is disturbed, damaging functioning of the cells [28]. Brain cavitations, from negative pressure because of translational acceleration insults from inertial inserting, may result in contrecoup contusions as the dura matter and skull begin to hasten prior to the brain on primary insult [16]. The pathophysiologic differences within contusions and peri contusions to the brain initiate that though contusions are known to be related to changes in immune response, and also to synaptic and mitochondrial damage [20] and are indicated by petechial hemorrhages, thrombosis, neuronal pyknosis, inflammation, and astrogliosis, [25] whereas peri contusions are related to modifications in the management of cytoskeletal and neurogenesis structural design [20] and are identified by neuropil vacuole formation, edema, axonal loss, and dystrophic changes [28]. Also, studies characterized that in relation to peri contusions, contusions result in more severe oxidative 


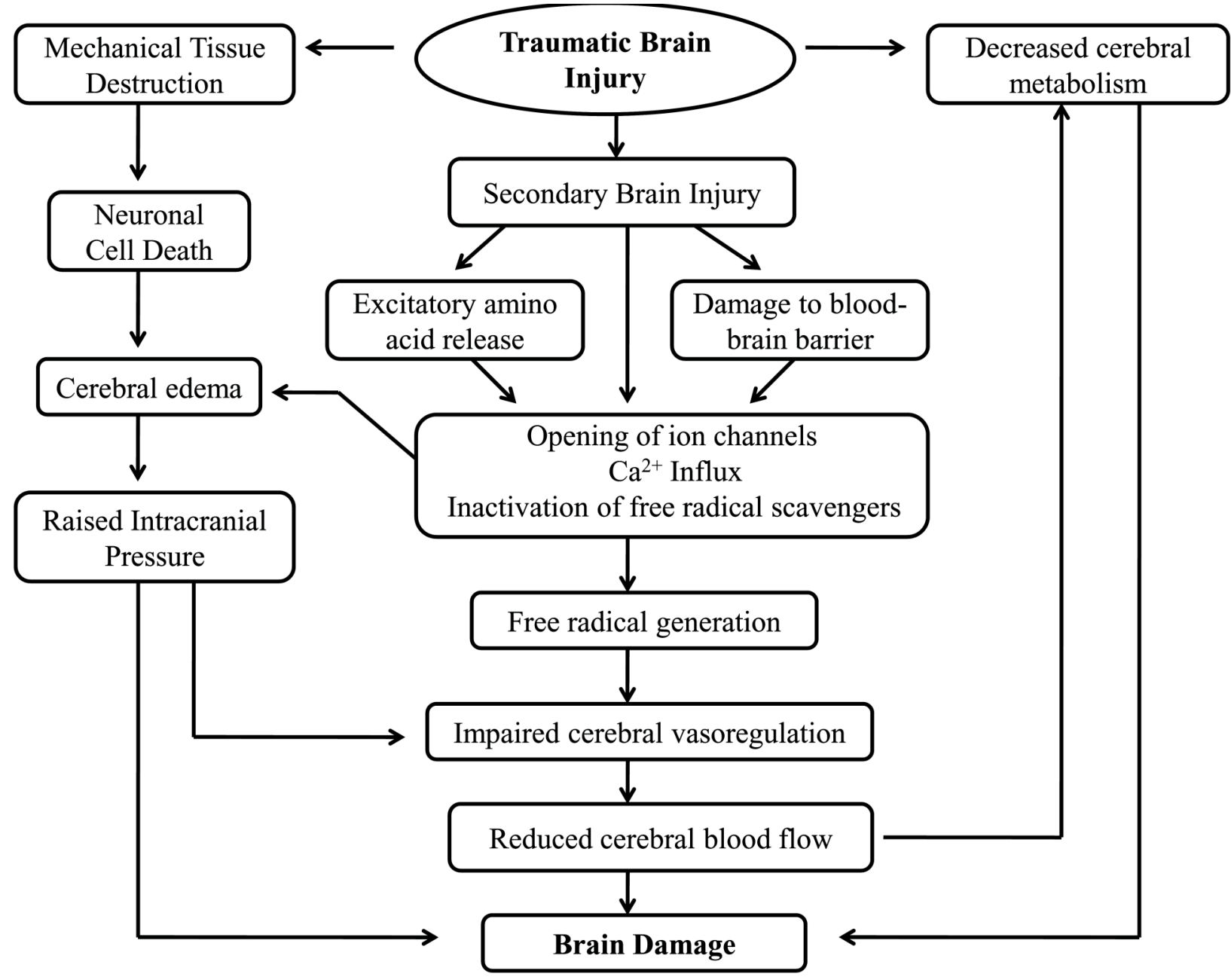

Fig. (2). Contributing events in the pathophysiology of Secondary Brain Injury.

damage, mitochondrial dysfunction, glutathione depletion, and synaptic protein loss [25].

\section{SECONDARY INJURY}

\subsection{Edema}

Intermittently after TBI, the formation of edema occurs (Fig. 2). The present categorization of edema associated with the structural harm and osmotic imbalance generated by the primary or secondary injury [28]. Brain edema is of 2 types:

$>$ cytotoxic (Intracellular).

$>$ vasogenic (Interstitial).

Both these types take place promptly after TBI and both may result in secondary impairments. Brain edema is normally worse at 24 to 48 hours post-injury [29]. In TBI victims, even though cytotoxic edema implies to be more common as compared to vasogenic edema, both these types result in elevated Intracranial pressure (ICP) and secondary ischaemic actions [30].

- Vasogenic brain edema is produced by autodigestive disturbance or mechanical/functional disintegration of the endothelial cell sheet (an important system of the blood-brain barrier) or from reflex dilatation of brain vessels [31]. The cerebral vascular endothelial wall breakdown promotes the unrestrained ion and protein removal from the intravascular to the interstitial (extracellular) brain parts with confirming water gathering. All this results in accumulation of volume in the extracellular space [32]. This vasodilation results in partial pressure of carbon dioxide within the arterial blood elevated as an outcome of ventilatory failure. Although usually associated to ICP, brain edema can also occur without a subsequent enhancement in ICP [29]. As the vasogenic edema leads to raising cerebral volume may primarily be equalized by alterations in brain tissue compliance. Compliance may be attained via the shunting of CSF to the spinal subarachnoid space, a reduction in CSF generation, an enhancement in CSF absorption, or the shunting of venous blood out of the cranium [33].

- Cytotoxic brain edema is identified by intracellular water gathering of astrocytes, microglia, neurons regardless of the reliability of the vascular endothelial wall [28]. Cytotoxic edema is the consequence of 
modifications in cellular osmolality with the consequential failure of the cell's capability to manage its ionic gradients [29]. This pathology is produced by improved cell membrane permeability for ions, ionic pump stoppage because of energy reduction, and cellular reabsorption of osmotically active solutes [33]. Damaged BBB and ischemia in various brain areas can also produce cytotoxic brain injury by the restoration of blood flow. Glial cells and neurons are mainly sensitive to cytotoxic cell damage. Cytotoxic edema, if prevalent, can be related to impeded blood flow, elevated ICPs, and ischemia, however not separately with permanent neurological devastation [29].

\subsection{Increased Intracranial Pressure}

TBI becomes elevated because of increased ICP, specifically, if the pressure enhances to $40 \mathrm{~mm} \mathrm{Hg}$ [34]. Cerebral perfusion pressure (CPP), defined as the force of blood which is flowing to the brain, is commonly invariable because of autoregulation, however for irregular mean arterial pressure (MAP) or irregular ICP; the cerebral perfusion pressure is accounted for by deducting the intracranial pressure from the mean arterial pressure: CPP $=$ MAP - ICP [35]. Elevated ICP resulting in ischemia through reducing CPP is a major disadvantage. As soon as ICP reaches the height of mean systemic pressure, it causes a drop in cerebral perfusion. The body's reaction to a drop in CPP causes an increase in systemic blood pressure and dilation of cerebral blood vessels [36]. All these processes enlarge the cerebral blood volume, that raises ICP, reducing CPP additionally which further leads to an extensive decrease in cerebral perfusion and flow, ultimately resulting in brain infarction and ischemia. Also, high blood pressure produces intracranial hematoma that bleeds faster, further enhancing ICP [35]. Increased pressure can also cause cerebral edema, cerebral hypoxia, hydrocephalus, and brain herniation. Amongst 76 effectively resuscitated TBI sufferers with organized ICP, $93 \%$ has an increased lactate/pyruvate ratio and $76 \%$ had decreased glucose [34].

\subsection{Mitochondrial Dysfunction}

After TBI, mitochondrial dysfunction results in free radical generation following apoptosis, so necessary treatment is required which particularly limits the secondary injury damage [37]. Reduction in cellular energy production is noticed in TBI sufferers and all these brain cellular changes impair neurologic functions [38]. Glutamate neurotoxicity induces mitochondrial injury in neuronal cells [39, 40]. After TBI, the release of glutamate is seen because of NMDA receptor excitation which develops a great intracellular $\mathrm{Ca}++$ gathering followed by overloading mitochondria with $\mathrm{Ca}++[41$, 42]. This $\mathrm{Ca}++$ perturbation enhances energy failure and these altered processes result in harmful damage to mitochondria [43]. Resultant mitochondrial $\mathrm{Ca}++$ load also modulates mitochondrial production of reactive nitrogen species (RNS), reactive oxygen species (ROS), and other free radicals generation [44]. These free radicals usually target the $\mathrm{Ca}++-$ loaded neural mitochondria which lead to protein alterations and production of mitochondrial membrane LP. The decrease in mitochondrial $\mathrm{Ca}++$ buffering ability, oxidative phosphorylation, mitochondrial respiration, and transport of ions [44] occur due to irreversible loss of mitochondrial processes [45]. Moreover, generation of mitochondrial permeability transition pore (mPTP) is the major devastating sequence of $\mathrm{Ca}++$ load in the inner mitochondrial membrane and dumping of the matrix $\mathrm{Ca}++$ pool back into the cytoplasm [46]. The mPTP is an abrupt rise in the interior mitochondrial membrane permeability permitting solutes of molecular mass less than that of 1500 Daltons to pass properly through the inner mitochondrial membrane [47]. This mitochondrial collapse depletes the cytoplasmic pool of ATP which aggravates energy failure and amplifies the rise in cytosolic $\mathrm{Ca}++$ and leads to delayed $\mathrm{Ca}++$ dysregulation [48]. Following glutamate neurotoxicity, the status of mitochondrial dysfunction demonstrates the mode of cell death, apoptotic versus necrotic and neuronal cell death [40]. Formation of mPTP following injury induces components of oxidative stress which pave the way for apoptosis by modulating mitochondrial cytochrome c discharge [49].

\subsection{Excitotoxicity}

Excitotoxicity is defined as a process in which neurons are injured as a result of over stimulations of the receptors like NMDA and AMPA receptor i.e. excitatory glutamate neurotransmitters $[50,51]$. Experimental and clinical reports demonstrate that within few minutes after TBI, extracellular glutamate level increases aggressively. Due to related energy failure and injury, immense neuron depolarization results in elevated extracellular glutamate levels [51, 52]. This increased glutamate produces elevated $\mathrm{Na}^{+}$and $\mathrm{Ca}^{2+}$ influx to the cell and finally leads to cell damage mechanisms due to high intracellular $\mathrm{Ca}^{2+}$ overload. Because of caspase activation, cell damage mechanisms result in apoptosis [53]. Glutamate excitotoxicity firstly occurs in the neurons, under situations where astrocytes characterize central resistance by glutamate reuptake $[54,55]$. In the existence of glutamate aspartate transporter (GLAST) and glutamate transporter1(GLT-1), astrocytes are known to be capable of taking up glutamate. Then the cells convert glutamate to glutamine and offer defense extensively in combination with other astrocytes attached via gap junction channels (GJCs). Even these events trigger catabolic processes such as BBB disintegration, the cellular effort to equalize for ionic gradients, heighten $\mathrm{Na}^{+} / \mathrm{K}^{+}$-ATPase action and then metabolic requirement, producing an intense loop of flow-metabolism uncoupling to the cell $[32,56]$.

\subsection{Oxidative Stress}

Oxidative stress is described as the imbalance between the production of free radical and the ability of the body to detoxify their damaging effect through neutralization by antioxidants. Oxidative stress involves reactive oxygen species production (generation of oxygen free radicals and related species such as nitric oxide, superoxide, hydrogen peroxide, peroxynitrite) in response to Traumatic Brain Injury [59, 60]. Excitotoxicity and depletion of the endogenous antioxidant process (such as superoxide dismutase, glutathione peroxidase, and catalase) cause excessive production of reactive oxygen species. This process is further responsible for protein oxidation, cleavage of DNA, cellular and vascular sys- 


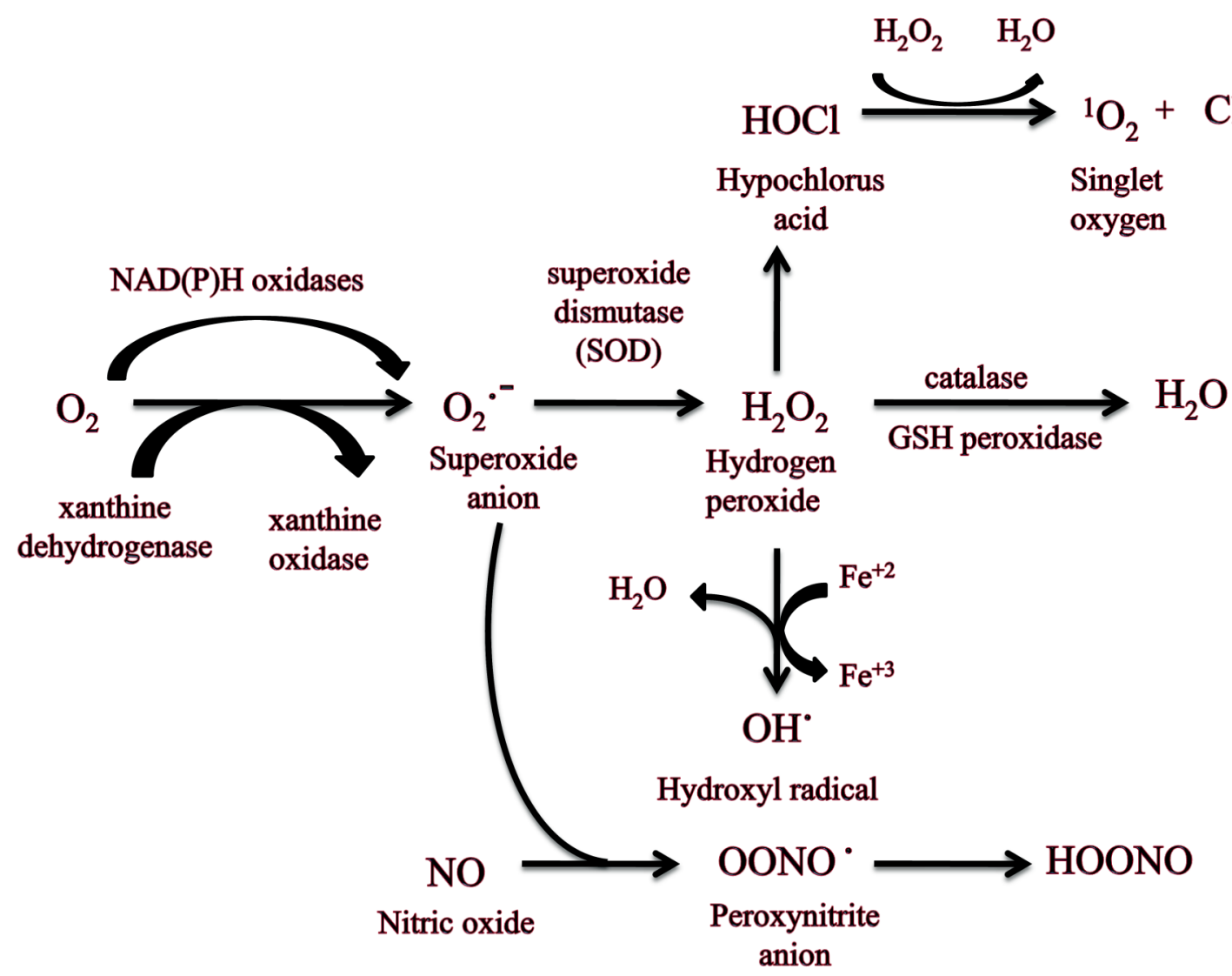

Fig. (3). Free radical generation that leads to oxidative stress. (The color version of the figure is available in the electronic copy of the article).

tem peroxidation and hence mitochondrial electron transport chain gets inhibited [59-61]. These mechanisms are capable enough to trigger the inflammatory processes, instant cell death, and initial or delayed apoptotic programs [60]. This increase in the generation of free radicals serves as one of the significant factors that lead to the TBI-promoted metabolic stress. Free radicals are extremely reactive as they have unpaired electrons. These seek for gaining electrons from neighboring bodies and causes damage to the protein, cell membrane, and DNA [62]. The two major species of free radicals are reactive nitrogen species (RNS) and reactive oxygen species (ROS). Normal metabolism causes generation of $\mathrm{O}$ and this family is an originator of hydrogen peroxide $(\mathrm{H} 2 \mathrm{O} 2)$, that further produce shydroxyl radicals $(\mathrm{OH})$ through the Fenton reaction [63]. This hydroxyl radical is one of the most reactive species. When $\mathrm{O}$ reacts with nitric oxide (NO), peroxynitrite (ONOO) is produced. ROS gets generated with normal metabolic activities which are organized by cellular antioxidant defense methods [62].

After cerebral injury, oxidative damage results due to elevated levels of ROS production that disturb scavenging system. The onset of TBI leads to the generation of superoxide radical which is generated first of all factors [64]. The superoxide radical $\left(\mathrm{O}_{2}{ }^{-}\right)$production takes place after TBI due to several factors of injury (Fig. 3). This includes one electron reduction process in which the molecular oxygen serves as the main part $\left(\mathrm{O}_{2}+\mathrm{e}-\rightarrow \mathrm{O}_{2}{ }^{-}\right)$. For example, change of xanthine dehydrogenase to xanthine oxidase along with the mitochondrial pour results in the production of $\mathrm{O}_{2}{ }^{-} \cdot$ [13] $\mathrm{Ca}^{++}$also acts by the developing action of phospholipases and the down- stream arachidonic acid system, enzymatic or autoxidation of biogenic amine neurotransmitters may also be sources of $\mathrm{O}_{2}{ }^{--}$after TBI [63]. $\mathrm{O}_{2}{ }^{--}$so formed is catabolized to produce $\mathrm{H}_{2} \mathrm{O}_{2}$ by enzyme superoxide dismutase [65]. $\mathrm{H}_{2} \mathrm{O}_{2}$ is reduced to $\mathrm{H}_{2} \mathrm{O}$ by catalase (in peroxisomes) and GSH (in cytosol and mitochondria). Hydroxyl radical is formed by radiolysis of water and/ or reaction of $\mathrm{H}_{2} \mathrm{O}_{2}$ with $\mathrm{Fe}^{+2}$ ions i.e. Fenton reaction. It produces damage of membrane by peroxidation of lipids, DNA destruction, proteins oxidation and the cytoskeletal deterioration that leads to the death of cells [13]. Nitric oxide (NO) appears as a neural mediator in the central nervous system. NO with superoxide $\left(\mathrm{O}_{2}{ }^{-}\right)$is elevated following TBI, producing extremely noxious species peroxynitrite (ONOO), which is a strong oxidant [66]. NO reversibly causes inhibition of respiration at cytochrome c oxidase, or irretrievably, following extended exposure, at numerous sites containing complex I (mainly subsequent to the alteration of NO to other RNS like ONOO-). Otherwise, NO may move the mitochondrial electron transport chain into an extra condensed state, increasing $\mathrm{O}_{2}{ }^{--}$formation [67]. This $\mathrm{O}_{2}{ }^{-}$enhances at lesser $\mathrm{NO}$ levels, which causes $\mathrm{H}_{2} \mathrm{O}_{2}$ production whereas elevated NO levels scavenge the $\mathrm{O}_{2}{ }^{-}$causing ONOO generation. Lastly, $\mathrm{NO}$ or other RNS may facilitate initiation of the mitochondrial permeability transition (MPT) which finally cause cell death [68]. 


\subsection{Cerebrovascular Autoregulation and $\mathrm{CO}_{2}$-reactivity}

The adequate maintenance of CPP and ICP can be carried out by $\mathrm{CO}_{2}$-reactivity and cerebrovascular autoregulation. Both of these two mechanisms have much importance in providing adequate CBF [69]. Secondary brain damage results in the impairment of these regulating mechanisms [70]. Constant CBF is maintained even at variable CPPs by cerebral autoregulation [71]. The difference between the mean arterial pressure and Intracranial Pressure is defined as CPP. The increasing or decreasing change in CPP leads to either cerebrovascular constriction or dilation. This process is termed as CBF autoregulation. This autoregulation is annihilated in many patients [72]. Temporal profile for this pathology is uncertain and is directly proportional to the severity of the injury that induces autoregulatory failure [73].

The development of defective autoregulation of CBF may be present directly after trauma or it may take some time to develop. This could be temporary or constant in nature despite the existence of moderate, mild, or severe damage [74]. Autoregulatory vasodilation is less resistant as compared to autoregulatory vasoconstriction. Hence, this shows that the patients are less sensitive to damage by high rather than low CPPs [33]. $50 \mathrm{~mm} \mathrm{Hg}$ or less CPP induces ischemia to brain tissues and also presents a failure of autoregulation. During this, the brain is mainly dependent on mean arterial pressure for perfusion. In this condition, the brain may regularize the decreased $\mathrm{CBF}$ by increasing oxygen extraction. But this remuneration has some limits. Thus, the low CPP gets directly converted into ischemic injury risk [75].

Cerebrovascular CO2-reactivity is the term used for cerebrovascular constriction or dilation in response to hypo or hypercapnia. This is a stronger phenomenon as compared to $\mathrm{CBF}$ autoregulation. In patients having severe brain injury and poor outcome, the $\mathrm{CO}_{2}$-reactivity is diminished at early stages after trauma [69]. In contrast to this, many other patients face intact or even enhanced $\mathrm{CO}_{2}$-reactivity and this further adds on to a physiological principle for targeting ICP management in hyperemic states $[76,77]$.

\subsection{Cerebral Metabolic Dysfunction}

Cerebral metabolism is indicated by cerebral oxygen and glucose consumption whereas cerebral energy state is indicated by the concentrations of ATP and phosphocreatine in tissue or indirectly by the ratio of lactate/pyruvate. These two factors are in decreased state following TBI and may present with significant spatial and temporal heterogeneity [78-80]. Primary injury is the main factor for the level of metabolic failure. Worse results are seen in patients having lesser metabolic rates in comparison to those with lower or no metabolic dysfunction [81].

The post-traumatic cerebral metabolism reduction involves the primary insult (immediate) resulting in dysfunction of mitochondria. This is also accompanied by an attenuated availability of the nicotinic co-enzyme pool, reduced respiratory rates and ATP-production and intramitochondrial $\mathrm{Ca}^{2+}$ overload $[82,83]$.

But, inconsistent results have been observed by using hyperoxia in order to reduce the metabolic failure [84]. The reduced cerebral metabolic demand may or may not be related to a reduction in $\mathrm{CBF}[79,80]$. This later effect shows the $\mathrm{CBF}$ and metabolism uncoupling. This is probably due to increase in adenosine availability [54, 79]. In some cases, a different pathophysiological event i.e. glucose hypermetabolism may occur $[85,86]$. The massive transmembrane ionic fluxes with consecutive neuroexcitation drive hypermetabolism. But these are not met efficiently increasing in CBF. The secondary ischaemic insults evolution is supported by uncoupling of CBF flow-metabolism [87].

\subsection{Excitatory Amino Acids}

Excitatory amino acids (EAAs) such as glutamate and aspartate, are considerably increased following TBI [8]. EAAs can result in neuronal death, cell vacuolization, and swelling. An entry of chloride, sodium, and calcium causes acute neuronal swelling occuring from EAAs and associated to loiter damage [88]. Along with N-methyl-D-aspartate receptor agonists, EAAs may diminish high energy phosphate stores (adenosine 5' -triphosphate, or ATP) or free radical production can be enhanced. EAAs can also lead to astrocytic swellings through volume-activated anion channels (VRACs) [89]. Tamoxifen, a known effective inhibitor of VRACs could possibly be of therapeutic value and hence reduce inflammation to a great extent. A recent cohort study on of TBI patients recognized increased excitatory amino acids in microdialysates of patients 50 times more than normal in approximately $30 \%$ of the patients; associations between secondary brain damage and excitatory amino acid quantity were also studied [53].

Glutamate is the primary excitatory amino acid. This is liberated by pre-synaptic vesicles or is released out of damaged membranes after TBI. Due to $\mathrm{Ca}^{2+}$ mediated release, glutamate rises and uptake of glial glutamate is reduced [90]. The glutamate release is associated with age, as it is increased in microdialysates of elderly TBI patients in comparison to younger TBI patients. But in the same study, some events such as cytokines had not quantitatively changed [91]. Studies confirmed that hyperexcitability and neuronal death are caused by increased glutamate activity in a dose-response relationship [92]. Subsequently, surplus glutamate attaches to the NMDA receptor and results in a huge influx of $\mathrm{Ca}^{2+}$ and $\mathrm{Na}^{+}$. This results in activation of a number of enzymes accountable for ensuring damage at the cellular level; astrocytes are susceptible to cell death by excitotoxicity-mediated manner [56]. Indeed, a NMDA receptor antagonist amantadine's administration in case of Fluid Percussion Injury (FPI) showed enhanced performance in Morris Water Maze (MWM). Also, survival of neurons in the CA2/CA3 pyramid of the hippocampus is encouraged [89].

\subsection{Cerebral Oxygenation}

TBI is indicated by an altered balance between the cerebral oxygen delivery and cerebral oxygen consumption [72]. Several different vascular and hemodynamic mechanisms are responsible for development in variance but the final outcome is brain tissue hypoxia [93]. The brain tissue oxygen pressure in patients undergoing TBI has been recognized as

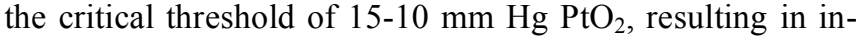
farction of neuronal tissue [94]. This has the outcomes like 
incidence, duration, and extent of tissue hypoxia, which are associated with poor consequence [95]. However, in the brain, oxygen insufficiency after secondary brain damage may result even in the state of normal CPP or ICP [96]. Additionally, several clinical protocols integrate the parameter of brain tissue oxygen pressure into executive algorithms as guided by ICP or CPP. This further adds important information about the relationship between oxygen delivery and oxygen demand and hence, establishes a better outcome from TBI. This outcome is seen when individualizing treatment is based on vital brain tissue oxygenation $[97,98]$.

\subsection{Inflammation}

TBI produces a multifaceted arrangement of immunological as well as inflammatory tissue responses [8]. Inflammation has dual effects on the brain tissue by one side producing damage and on another hand it promotes regeneration. For instance, the activation of microglia promotes recovery by the process involving phagocytosis of debris. However, this excessive cytokine and chemokine secretion extend the inflammatory process [99]. Several studies have strongly shown the neuroprotective as well as pro- regenerative role of microglia in the injured CNS but in a controlled manner [100]. The displacement of afferent synapses and close physical proximity of axotomized neurons to several microglial cells results in the removal of excitatory input. This may aid activation of microglia in order to have targeted delivery of growth factors to injured neurons. This supports the idea that inflammation of microglial is required to facilitate neuronal regeneration [101]. Additionally, various in vivo observations are present that are in disagreement with the idea of involvement of activated microglia that causes damage following CNS injury [102]. In addition to this, the presence of activated microglia in damaged tissue areas does not cause additional neurodegeneration in adjacent areas [103]. On the other hand, both primary and secondary injuries activate the discharge of cellular mediators involving proinflammatory cytokines, prostaglandins, free radicals, and complement [104]. These processes stimulate chemokines and adhesion molecules and in line, mobilize immune and glial cells in a parallel and synergistic manner [105]. For example, activated polymorphonuclear leukocytes remain defective and the entire endothelial cell layers as mediated via adhesion molecules. These cells infiltrate injured tissue along with macrophages and T-cell lymphocytes [106]. Upregulation of cellular adhesion molecules such as ICAM-1(intercellular adhesion molecules), VCAM-1 (vascular adhesion molecules) and P-selectin facilitates tissue infiltration of leucocytes. In response to these inflammatory processes, adjacent and injured tissue (based on 'spreading depressions') are eliminated and within hours, days, and weeks, astrocytes produce microfilaments and neurotrophins ultimately to synthesize scar tissue [107]. Within hours from injury, proinflammatory enzymes such as tumor necrosis factor, interleukin-1- $\beta$, and interleukin-6 are upregulated [8]. The progression of tissue damage is related to direct discharge of neurotoxic mediators or indirectly to the release of nitric oxide and cytokines [104]. The additional release of vasoconstrictors (leukotrienes and prostaglandins), the destruction of microvasculature through adhesion of leucocytes and platelets, the blood-brain barrier lesion, and formation of edema further reduce tissue perfusion and consequently worsen secondary brain damage [106].

\subsection{Cerebral Vasospasm}

Essential secondary impairment is the post-traumatic cerebral vasospasm which calculates the basic outcome of the patient $[108,109]$. Cerebral vasospasm after spontaneous subarachnoid hemorrhage (SAH) because of aneurysmal rupture has been one of the most widely studied areas in TBI [56]. Vasospasm occurs in approx $30 \%$ of TBI injury victims which results in serious harm to a brain and hypoperfusion (hemodynamically considerable vasospasm) occurs in approx $50 \%$ of victims undergoing vasospasm. The mechanism through which vasospasm is caused involves persistent depolarization of vascular smooth muscles owing to decrease in potassium channel action, [110] discharge of endothelin through decreased accessibility of nitric oxide, [111] vascular smooth muscles cyclic GMP reduction, [112] potentiating prostaglandin-promoting vasoconstriction [113] and development of free radicals $[33,77]$. Thus, a decline in morbidity and mortality is better attained by lessening secondary injury, [114] resulting in potential brain ischemia after vasospasm.

\subsection{Necrosis vs. Apoptosis}

Two diverse kinds of cell death results following TBI: apoptosis (programmed cell death) and necrosis. Reaction to serious mechanical or ischemic/hypoxic tissue destruction via extreme discharge of excitatory amino acid neurotransmitter and metabolic dysfunction results in necrosis [115]. Later, biological membranes lysis via proteases, lipid peroxidases and phospholipases. Apoptosis of glia and neurons is largely towards the intact TBI pathology in animals and humans both [116]. On the contrary, neurons that have undergone apoptosis are undamaged morphologically throughout the instant post-traumatic stage with sufficient adenosine triphosphate generation resulting in physiological membrane potential and are recognized within contusions inside areas distant from the location of insult during the days and weeks following impairments [104]. In the injured white matter tracts, apoptotic oligodendrocytes and astrocytes are seen. Phosphatidylserine translocation includes distinct however gradual membrane breakdown together with nuclear membranes disintegration, DNA-fragmentation, and chromatin condensation [117]. While enhancement in intracellular calcium, free radicals, and excitatory amino acids can produce cells to experience apoptosis, in vitro experiments have shown that neural cells can experience apoptosis through various pathways [114]. It is normally studied that alteration into the equilibrium among anti- \& pro-apoptotic protein factors toward the expression of proteins which contribute to death, is one procedure that originates in cell death of apoptosis [115]. Successive deactivation and activation of caspases, that characterize particular proteases of the interleukin-converting enzyme species, have been determined as essential mediators of programmed death of cells [114]. The result of TBI on district cellular pattern of appearance of survival inducing-proteins like Bcl-xL, Bcl-2, and extracellular signal-regulated kinases, and death-promoting proteins 
including the tumor-suppressor gene, p53, Bax, c-Jun Nterminal kinase, and the caspase species of proteases are also essential factors to be examined [118].

\subsection{Glucose Metabolism}

Initial damage after TBI frequently originates commencing the ischemic cascade. Disruption of normal energy processes leads to lactic acid accumulation, decreased glucose utilization, decreased adenosine triphosphate and action of adenosine triphosphate-reliant ion pump, excitotoxicity, $\mathrm{Ca}^{2+}$ promoting depolarization and cellular death [119].

Experimental studies have shown that TBI causes considerable enhancement of glucose utilization following the initial 30 minutes post-injury, followed by a decline in glucose uptake and then is maintained in a low state for around 5-10 days [120, 121]. Reduced cerebral glucose metabolism was noted in both severe and mild TBI patients, indicating that noticeable global neurometabolic abnormalities may be present with or without remarkable clinical symptoms [122]. After both ischemic and concussive brain injuries, increased lactate levels are observed [123, 124] which may produce neuronal dysfunction because of interruption of the BBB, acidosis, cerebral edema, and membrane damage [125]. There is, in addition, a few manifestations reveal that lactate gathering post-injury may make the neurons more vulnerable to secondary ischemic insults [126]. Several investigators have also shown an increase in lactate concentration in cerebrospinal fluid and in brain tissue in the early 60 minutes after mild to moderate fluid percussion injury in rat models $[127,128]$. Moreover, at least in patients with comparatively conserved oxidative metabolism, brain uptake of lactate has been associated with enhanced outcome [87].

\subsection{Hypoperfusion and Hyperperfusion}

The effect of TBI on CBF has been investigated from various studies on laboratory animals and humans. TBI patients may acquire cerebral hyperperfusion (CBF $>55 \mathrm{ml} 100$ g-1 min-1) during the primary levels of damage [129]. Relationship between cerebral hypoperfusion and poor result demonstrates that ischemic stroke and TBI deal with similar basic mechanisms, however, this hypothesis may be accurate to a some extent [33]. For instance, CBF critical threshold for the generation of irreparable tissue harm is $15 \mathrm{ml} 100 \mathrm{~g}^{-1}$ $\mathrm{min}^{-1}$ in TBI victims in relation to $5-8.5 \mathrm{ml} 100 \mathrm{~g}^{-1} \mathrm{~min}^{-1}$ in ischemic stroke victims, which is the key difference occurring within these dissimilar kinds of primary impairments [78]. Cerebral ischemia generally results in ionic disturbance and metabolic trauma [130]. Head shock exposes the brain tissues to shear forces, following structural damage of neuronal bodies of cells, cerebral microvascular, astrocytes, microglia, and endothelial cell damage [131]. It is important to note that increase in $\mathrm{CBF}$ above the needed metabolic demand, involves vasoparalysis through successive elevation in cerebral blood volume and consecutively, leads to ICP [132]. It is essential to study that treating hyperperfusion or hypoperfusion is important only after determining CBF measurements in association with cerebral oxygen utilization [133] Cerebral ischemia and hyperemia both mention a difference among cerebral metabolism and $\mathrm{CBF}$. For instance, less $\mathrm{CBF}$ along with elevated metabolic rate indicates an ischemic condition while elevated CBF along with decreased metabolic rate indicates cerebral hyperemia [134].

\subsection{Endogenous Opioid Peptides}

By regulating the presynaptic release of EAAs neurotransmitters, endogenous opioid peptides make a contribution to the exacerbation of neurologic damage [119]. Behavioral suppression is affected because of stimulation of the muscarinic cholinergic processes within the rostral pons, that is frequently noticed in TBI. Elevated metabolism in the damaged brain is encouraged with an enhancement in the flow amounts of catecholamines against the TBI-mediated motivation of the sympathoadrenomedullary axis and serotonergic structures (by a related depression within glucose consumption), resulting in brain damage [8]. Further biochemical methods causing larger extremity of damage include extracellular potassium elevation, resulting in edema, cytokines elevation, causing inflammation, thereby resulting in calcium influx due to a reduction in intracellular magnesium [121]. Dependent on the astrocytes outcome are the cells which display hyperplastic and hypertrophic actions to the central nervous systems (CNS). Enlarged generation of protein kinase $\mathrm{B} / \mathrm{Akt}$ during $\mathrm{P} 2$ purinergic receptors stimulation is observed in TBI for neuronal survival [88].

\subsection{Hydrocephalus}

Studies introduced the classification of hydrocephalus as either noncommunicating or communicating.

The more common type of hydrocephalus is the communicating hydrocephalus whereas the noncommunicating form of hydrocephalus is less known [135]. On the contrary, in communicating hydrocephalus (also known to as nonobstructive hydrocephalus), complete communication among the ventricles and the subarachnoid space occurs. Diminished CSF absorption may lead to communicating hydrocephalus [136]. The communicating type is normally the consequence of pressure from blood products that allow difficulty in the course of CSF in the subarachnoid space and CSF absorption via the arachnoid villi [137]. Severe skull fractures hemorrhage and meningitis may influence patients to this alternative of PTH. Studies proposed that Posttraumatic Hydrocephalus (PTH) develops as a result of increased dural sinus pressure, causing reduced CSF outflow [138]. Normal Pressure Hydrocephalus (NPH), the form of communicating the type of hydrocephalus, may be a consequence of subarachnoid hemorrhage caused by encephalopathy, or Alzheimer disease, aneurysm rupture or a TBI [139]. $\mathrm{NPH}$ often presents as the classic triad of an increased gait disorder, damage of mental function, and urinary incontinence [140]. In NPH, ventricles increase despite normal or even slightly decreased intracranial pressure, and are pressed against brain parenchyma.

The noncommunicating hydrocephalus usually results from blood coagulate hindrance of blood flow on the cerebral aqueduct, or fourth ventricle, interventricular foramen and third ventricle [141]. In obstructive hydrocephalus (another name of noncommunicating hydrocephalus), CSF gathers in the ventricles because of CSF flow obstruction 
which causes the enlargement of ventricles and the hemispheres expand [142].

\subsection{Brain Herniation}

Brain herniation is possibly a harmful side effect of high pressure developed within the skull. This exists when a part of the brain gets squeezed across structures in the skull. There are a number of factors that produce herniation such as Traumatic brain injury, brain tumor, or intracranial hemorrhage. These generate a mass effect and increase ICP [143]. There are two major classes of herniation.

1. Supratentorial

2. Infratentorial

Supratentorial herniation is imputable to absolute mechanical compression due to an assembling mass or to increased intracranial pressure. The following five types of supratentorial herniation are recognized:

\subsubsection{Subfalcine Herniation}

Subfalcine herniation is the most known type of herniation. In this, the cingulated gyrus of the frontal lobe is pushed beneath the falx cerebric when an expanding mass lesion results in a medial shift of the ipsilateral hemisphere [144].

\subsubsection{Central Transtentorial Herniation}

This type of injury is corroborated by the displacement of the cerebral hemispheres and basal nuclei downward while the diencephalon and adjacent midbrain are squeezed via the tentorial notch.

\subsubsection{Uncal Herniation}

This type of injury involves the displacement of the medial edge of the hippocampal gyrus and the uncus medially and over the ipsilateral edge of the uncus. The hippocampal gyrus medially and over the ipsilateral edge of the tentorium cerebella foramen causes compression of the midbrain and the ipsilateral or contralateral third nerve may be stretched or compressed [145].

\subsubsection{Cerebellar Herniation}

This injury is manifested by an infratentorial herniation in which foramen magnum compresses the tonsil of the cerebellum. This squeezes and compresses the medulla, leading to respiratory arrest and bradycardia.

\subsubsection{Transcalvarial Herniation}

In trans calvarial herniation, the brain gets compressed in the skull during a fracture or at a surgical site. Also known as "external herniation". This type of herniation may occur during craniectomy (removal of skull flap by the help of a surgery) preventing the piece of skull from being replaced [146].

The following two types of infratentorial herniation are recognized:

\subsubsection{Upward Herniation}

Increased pressure in the posterior fossa can result in the movement of the cerebellum in upward direction through the tentorial opening or cerebellar herniation. Tentorial notch squeezes the midbrain and this also compresses the midbrain down [145]. This is also known as a transtentorial herniation since it occurs across the tentorium cerebella.

\subsubsection{Tonsillar Herniation}

Tonsillar herniation, also known as transforaminal herniation, is downward cerebellar herniation, or "coning". The downward shifting of cerebellar tonsils by the foramen magnum leads to compression of the lower brainstem and upper cervical spinal cord. This occurs as they pass throughout the foramen magnum. Dysfunction of the centers in the brain can be made due to increased pressure on the brainstem; centers are accountable for controlling cardiac and respiratory function. Tonsillar impaction results in the signs like head tilt, neck stiffness, and intractable headache [146]. This can account for unconsciousness or flaccid paralysis along with instability in the blood pressure in these patients.

\section{CONCLUSION}

TBI or Traumatic Brain Injury is a sudden process and may cause a number of complications afterwards. This single dynamic process includes a large number of pathological cellular pathways. This may be initially characterized by the physical force which damages the brain tissue and changes the function and normal physiology. This is not an easy task to understand, diagnose or treat TBI due to diversity in the symptomatic presentation; this gets altered with each individual, type and severity of the injury, gender, and age. Survival after TBI is difficult due to inadequacy in attention, cognition, severe depression, processing of information as well as progression towards other forms of neurodegenerative diseases. The mechanical stress results in brain tissue damage along with an imbalance between CBF and metabolism, inflammatory and apoptotic processes, excitotoxicity and the edema formation. Proper knowledge regarding multidimensional cascade of TBI may provide many therapeutic options including management of hyper- (mechanical) ventilation, to reduce intracranial pressure and recover oxygenation by the help of kinetic therapy. Many types of pharmacological interventions can be done to reduce the intracranial pressure and excitotoxicity. A proper monitoring of the injured brain is necessary to adapt to the treatment according to the specific status of the patients. Proper research efforts are needed to identify the common underlying pathological responses in TBI to provide possible therapeutic options for early intervention for patients of all age groups. The current review aims to cover the pathophysiology following from TBI, starting with the initial impact followed by the secondary complications after injury. Although, many research efforts have been made in this area but we still lack in proper knowledge. With an increased understanding of the pathophysiology of brain injury, there can be a great promise for providing different therapies in future. But until then, there are more failures than successes.

\section{LIST OF ABBREVIATIONS}

$\begin{array}{ll}\text { ATP } & =\text { adenosine 5'-triphosphate } \\ \text { BBB } & =\text { Blood Brain Barrier }\end{array}$




$\begin{array}{lll}\mathrm{CBF} & =\text { Cerebral blood flow } \\ \mathrm{CDC} & =\text { Centers for Disease Control } \\ \mathrm{CFS} & =\text { Cerebrospinal fluid } \\ \mathrm{CNS} & =\text { Central nervous systems } \\ \mathrm{CPP} & =\text { Cerebral perfusion pressure } \\ \mathrm{DAI} & =\text { Diffuse axonal injury } \\ \mathrm{EAAs} & =\text { Excitatory amino acids } \\ \mathrm{H}_{2} \mathrm{O}_{2} & =\text { Hydrogen peroxide } \\ \mathrm{ICP} & =\text { Intracranial pressure } \\ \mathrm{MAP} & =\text { Mean arterial pressure } \\ \mathrm{mPTP} & =\text { mitochondrial permeability transition pore } \\ \mathrm{NMDA} & =\text { N-methyl-D-aspartate } \\ \mathrm{NPH} & =\text { Normal Pressure Hydrocephalus } \\ \mathrm{O}_{2}{ }^{\circ-} & =\text { superoxide radical } \\ \mathrm{PTH} & =\text { Posttraumatic Hydrocephalus } \\ \mathrm{RNS} & =\text { Reactive nitrogen species } \\ \mathrm{ROS} & =\text { Reactive oxygen species } \\ \mathrm{TBI} & =\text { Traumatic brain injury } \\ \mathrm{VRACs} & =\text { Volume -activated anion channels }\end{array}$

\section{CONSENT FOR PUBLICATION}

Not applicable.

\section{CONFLICT OF INTEREST}

The authors declare no conflict of interest, financial or otherwise.

\section{ACKNOWLEDGEMENTS}

Declared none.

\section{REFERENCES}

[1] Langlois, J.A.; Rutland-Brown, W.; Wald, M.M. The epidemiology and impact of traumatic brain injury: a brief overview. J. Head Trauma Rehabil., 2006, 21(5), 375-378. [http://dx.doi.org/10.1097/ 00001199-200609000-00001] [PMID: 16983222]

[2] Thurman, D. Traumatic Brain Injury in the United States: A Report to Congress; Centers for Disease Control and Prevention, 1999.

[3] Freire, M.A. Pathophysiology of neurodegeneration following traumatic brain injury. West Indian Med. J., 2012, 61(7), 751-755. [PMID: 23620976]

[4] Thurman, D.J.; Alverson, C.; Browne, D.; Dunn, K.A.; Guerrero, J.; Johnson, R.; Johnson, V.; Langlois, J.; Pilkey, D.; Sniezek, J.E. Traumatic brain injury in the United States: A report to Congress;

[5] Nolan, S. Traumatic brain injury: a review. Crit. Care Nurs. Q., 2005, 28(2), 188-194. [http://dx.doi.org/10.1097/00002727-20050400000010] [PMID: 15875448]

[6] Scholten, A.C.; Haagsma, J.A.; Panneman, M.J.; van Beeck, E.F.; Polinder, S. Traumatic brain injury in the Netherlands: incidence, costs and disability-adjusted life years. PLoS One, 2014, 9(10), e1 10905. [http://dx.doi.org/10.1371/journal.pone.0110905] [PMID: 25343447]

[7] Gubata, M.E.; Packnett, E.R.; Blandford, C.D.; Piccirillo, A.L.; Niebuhr, D.W.; Cowan, D.N. Trends in the epidemiology of disability related to traumatic brain injury in the US Army and Marine
Corps: 2005 to 2010. J. Head Trauma Rehabil., 2014, 29(1), 6575. [http://dx.doi.org/10.1097/HTR.0b013e318295f590] [PMID: 23756433]

[8] Werner, C.; Engelhard, K. Pathophysiology of traumatic brain injury. Br. J. Anaesth., 2007, 99(1), 4-9. [http://dx.doi.org/10.1093/ bja/aem131] [PMID: 17573392]

[9] Prins, M.; Greco, T.; Alexander, D.; Giza, C.C. The pathophysiology of traumatic brain injury at a glance. Dis. Model. Mech., 2013 , 6(6), 1307-1315. [http://dx.doi.org/10.1242/dmm.011585] [PMID: 24046353]

[10] Marshall, L.F. Head injury: recent past, present, and future. Neurosurgery, 2000, 47(3), 546-561. [PMID: 10981741]

[11] Nortje, J.; Menon, D.K. Traumatic brain injury: physiology, mechanisms, and outcome. Curr. Opin. Neurol., 2004, 17(6), 711-718. [http://dx.doi.org/10.1097/00019052-200412000-00011] [PMID: 15542980]

[12] Baethmann, A.; Eriskat, J.; Stoffel, M.; Chapuis, D.; Wirth, A.; Plesnila, N. Special aspects of severe head injury: recent developments. Curr. Opin. Anaesthesiol., 1998, 11(2), 193-200. [http://dx. doi.org/10.1097/00001503-199804000-00013] [PMID: 17013219]

[13] Mustafa, A.G.; Alshboul, O.A. Pathophysiology of traumatic brain injury. Neurosciences (Riyadh), 2013, 18(3), 222-234. [PMID: 23887212]

[14] Smith-Seemiller, L.; Lovell, M.R.; Smith, S.; Markosian, N.; Townsend, R.N. Impact of skull fracture on neuropsychological functioning following closed head injury. Brain Inj., 1997, 11 (3), 191-196. [http://dx.doi.org/10.1080/026990597123638] [PMID: 9058000]

[15] Langlois, J.A.; Rutland-Brown, W.; Thomas, K.E. The incidence of traumatic brain injury among children in the United States: differences by race. J. Head Trauma Rehabil., 2005, 20(3), 229238. [http://dx.doi.org/10.1097/00001199-200505000-00006] [PMID: 15908823]

[16] Dawodu, S.; Kishner, S. Traumatic brain injury (TBI)-Definition and pathophysiology. Medscape website. 2016.

[17] Niedzwecki, C.M.; Marwitz, J.H.; Ketchum, J.M.; Cifu, D.X.; Dillard, C.M.; Monasterio, E.A. Traumatic brain injury: a comparison of inpatient functional outcomes between children and adults. J. Head Trauma Rehabil., 2008, 23(4), 209-219. [http://dx.doi.org/ 10.1097/01.HTR.0000327253.61751.29] [PMID: 18650765]

[18] Haring, R.S.; Narang, K.; Canner, J.K.; Asemota, A.O.; George, B.P.; Selvarajah, S.; Haider, A.H.; Schneider, E.B. Traumatic brain injury in the elderly: morbidity and mortality trends and risk factors. J. Surg. Res., 2015, 195(1), 1-9. [http://dx.doi.org/10.1016/ j.jss.2015.01.017] [PMID: 25724764]

[19] Steyerberg, E.W.; Mushkudiani, N.; Perel, P.; Butcher, I.; Lu, J.; McHugh, G.S.; Murray, G.D.; Marmarou, A.; Roberts, I.; Habbema, J.D.F.; Maas, A.I. Predicting outcome after traumatic brain injury: development and international validation of prognostic scores based on admission characteristics. PLoS Med., 2008, 5(8), e165. [http://dx.doi.org/10.1371/journal.pmed.0050165] [PMID: $18684008]$

[20] Hellewell, S. C.; Ziebell, J. M.; Lifshitz, J.; Morganti-Kossmann, M. C. Impact acceleration model of diffuse traumatic brain injury. Injury Models of the Central Nervous System: Methods and Protocols 2016, 253-266.

[21] Yellinek, S.; Cohen, A.; Merkin, V.; Shelef, I.; Benifla, M. Clinical significance of skull base fracture in patients after traumatic brain injury. J. Clin. Neurosci., 2016, 25, 111-115. [http://dx.doi.org/ 10.1016/j.jocn.2015.10.012] [PMID: 26724846]

[22] Rosenfeld, J.V.; Maas, A.I.; Bragge, P.; Morganti-Kossmann, M.C.; Manley, G.T.; Gruen, R.L. Early management of severe traumatic brain injury. Lancet, 2012, 380(9847), 1088-1098. [http:// dx.doi.org/10.1016/S0140-6736(12)60864-2] [PMID: 22998718]

[23] Ommaya, A.K.; Grubb, R.L., Jr; Naumann, R.A. Coup and contrecoup injury: observations on the mechanics of visible brain injuries in the rhesus monkey. J. Neurosurg., 1971, 35(5), 503-516. [http://dx.doi.org/10.3171/jns.1971.35.5.0503] [PMID: 5000943]

[24] Yan, E.B.; Johnstone, V.P.; Alwis, D.S.; Morganti-Kossmann, MC.; Rajan, R. Characterising effects of impact velocity on brain and behaviour in a model of diffuse traumatic axonal injury. Neuroscience, 2013, 248, 17-29. [http://dx.doi.org/10.1016/j.neuroscience. 2013.05.045] [PMID: 23735754]

[25] Harish, G.; Mahadevan, A.; Pruthi, N.; Sreenivasamurthy, S.K.; Puttamallesh, V.N.; Keshava Prasad, T.S.; Shankar, S.K.; Srinivas 
Bharath, M.M.; Mukunda, M. Characterization of traumatic brain injury in human brains reveals distinct cellular and molecular changes in contusion and pericontusion. J. Neurochem., 2015, 134(1), 156-172. [http://dx.doi.org/10.1111/jnc.13082] [PMID: 25712633]

[26] Hellewell, S.C.; Yan, E.B.; Agyapomaa, D.A.; Bye, N.; MorgantiKossmann, M.C. Post-traumatic hypoxia exacerbates brain tissue damage: analysis of axonal injury and glial responses. J. Neurotrauma, 2010, 27(11), 1997-2010. [http://dx.doi.org/10.1089/neu. 2009.1245] [PMID: 20822466]

[27] Mac Donald, C.L.; Johnson, A.M.; Cooper, D.; Nelson, E.C.; Werner, N.J.; Shimony, J.S.; Snyder, A.Z.; Raichle, M.E.; Witherow, J.R.; Fang, R.; Flaherty, S.F.; Brody, D.L. Detection of blast-related traumatic brain injury in U.S. military personnel. $N$. Engl. J. Med., 2011, 364(22), 2091-2100. [http://dx.doi.org/10. 1056/NEJMoa1008069] [PMID: 21631321]

[28] Smith-Seemiller, L.; Fow, N.R.; Kant, R.; Franzen, M.D. Presence of post-concussion syndrome symptoms in patients with chronic pain vs mild traumatic brain injury. Brain Inj., 2003, 17(3), 199206. [http://dx.doi.org/10.1080/0269905021000030823] [PMID: 12623496]

[29] Unterberg, A.W.; Stover, J.; Kress, B.; Kiening, K.L. Edema and brain trauma. Neuroscience, 2004, 129(4), 1021-1029. [http://dx. doi.org/10.1016/j.neuroscience.2004.06.046] [PMID: 15561417]

[30] Betz, A.; Crockard, A. Brain edema and the blood brain barrier., 1992.

[31] Marmarou, A.; Fatouros, P.P.; Barzó, P.; Portella, G.; Yoshihara, M.; Tsuji, O.; Yamamoto, T.; Laine, F.; Signoretti, S.; Ward, J.D.; Bullock, M.R.; Young, H.F. Contribution of edema and cerebral blood volume to traumatic brain swelling in head-injured patients. J. Neurosurg., 2000, 93(2), 183-193. [http://dx.doi.org/10.3171/ jns.2000.93.2.0183] [PMID: 10930002]

[32] Marmarou, A.; Signoretti, S.; Fatouros, P.P.; Portella, G.; Aygok, G.A.; Bullock, M.R. Predominance of cellular edema in traumatic brain swelling in patients with severe head injuries. J. Neurosurg., 2006, 104(5), 720-730. [http://dx.doi.org/10.3171/jns.2006.104. 5.720] [PMID: 16703876]

[33] DeWitt, D.S.; Prough, D.S. Traumatic cerebral vascular injury: the effects of concussive brain injury on the cerebral vasculature. $J$. Neurotrauma, 2003, 20(9), 795-825. [http://dx.doi.org/10.1089/ 089771503322385755] [PMID: 14577860]

[34] Stiefel, M.F.; Tomita, Y.; Marmarou, A. Secondary ischemia impairing the restoration of ion homeostasis following traumatic brain injury. J. Neurosurg., 2005, 103(4), 707-714. [http://dx.doi.org/10. 3171/jns.2005.103.4.0707] [PMID: 16266054]

[35] Stein, N.R.; McArthur, D.L.; Etchepare, M.; Vespa, P.M. Early cerebral metabolic crisis after TBI influences outcome despite adequate hemodynamic resuscitation. Neurocrit. Care, 2012, 17(1), 4957. [http://dx.doi.org/10.1007/s12028-012-9708-y] [PMID: 22528283]

[36] Steiner, L.A.; Andrews, P.J. Monitoring the injured brain: ICP and CBF. Br. J. Anaesth., 2006, 97(1), 26-38. [http://dx.doi.org/10. 1093/bja/ael110] [PMID: 16698860]

[37] Duschek, S.; Schandry, R. Reduced brain perfusion and cognitive performance due to constitutional hypotension. Clin. Auton. Res., 2007, 17(2), 69-76. [http://dx.doi.org/10.1007/s10286-006-0379-7] [PMID: 17106628]

[38] Robertson, C.L. Mitochondrial dysfunction contributes to cell death following traumatic brain injury in adult and immature animals. $J$. Bioenerg. Biomembr., 2004, 36(4), 363-368. [http://dx.doi.org/ 10.1023/B:JOBB.0000041769.06954.e4] [PMID: 15377873]

[39] Sullivan, P.G.; Thompson, M.B.; Scheff, S.W. Cyclosporin A attenuates acute mitochondrial dysfunction following traumatic brain injury. Exp. Neurol., 1999, 160(1), 226-234. [http://dx. doi.org/10.1006/exnr.1999.7197] [PMID: 10630207]

[40] Lifshitz, J.; Sullivan, P.G.; Hovda, D.A.; Wieloch, T.; McIntosh, T.K. Mitochondrial damage and dysfunction in traumatic brain injury. Mitochondrion, 2004, 4(5-6), 705-713. [http://dx.doi.org/10. 1016/j.mito.2004.07.021] [PMID: 16120426]

[41] Ankarcrona, M.; Dypbukt, J.M.; Bonfoco, E.; Zhivotovsky, B.; Orrenius, S.; Lipton, S.A.; Nicotera, P. Glutamate-induced neuronal death: a succession of necrosis or apoptosis depending on mitochondrial function. Neuron, 1995, 15(4), 961-973. [http://dx.doi. org/10.1016/0896-6273(95)90186-8] [PMID: 7576644]

[42] Mark, L.P.; Prost, R.W.; Ulmer, J.L.; Smith, M.M.; Daniels, D.L.; Strottmann, J.M.; Brown, W.D.; Hacein-Bey, L. Pictorial review of glutamate excitotoxicity: fundamental concepts for neuroimaging.
AJNR Am. J. Neuroradiol., 2001, 22(10), 1813-1824. [PMID: $11733308]$

[43] Nicholls, D.G.; Ward, M.W. Mitochondrial membrane potential and neuronal glutamate excitotoxicity: mortality and millivolts. Trends Neurosci., 2000, 23(4), 166-174. [http://dx.doi.org/ 10.1016/S0166-2236(99)01534-9] [PMID: 10717676]

[44] Xiong, Y.; Gu, Q.; Peterson, P.L.; Muizelaar, J.P.; Lee, C.P. Mitochondrial dysfunction and calcium perturbation induced by traumatic brain injury. J. Neurotrauma, 1997, 14(1), 23-34. [http://dx. doi.org/10.1089/neu.1997.14.23] [PMID: 9048308]

[45] Brustovetsky, N.; Brustovetsky, T.; Jemmerson, R.; Dubinsky, J.M. Calcium-induced cytochrome c release from CNS mitochondria is associated with the permeability transition and rupture of the outer membrane. J. Neurochem., 2002, 80(2), 207-218. [http://dx.doi. org/10.1046/j.0022-3042.2001.00671.x] [PMID: 11902111]

[46] Singh, I.N.; Sullivan, P.G.; Deng, Y.; Mbye, L.H.; Hall, E.D. Time course of post-traumatic mitochondrial oxidative damage and dysfunction in a mouse model of focal traumatic brain injury: implications for neuroprotective therapy. J. Cereb. Blood Flow Metab., 2006, 26(11), 1407-1418. [http://dx.doi.org/10.1038/sj.jcbfm. 9600297] [PMID: 16538231]

[47] Nicholls, D.G.; Budd, S.L. Mitochondria and neuronal survival. Physiol. Rev., 2000, 80(1), 315-360. [http://dx.doi.org/10.1152/ physrev.2000.80.1.315] [PMID: 10617771]

[48] Sullivan, P.G.; Rabchevsky, A.G.; Waldmeier, P.C.; Springer, J.E. Mitochondrial permeability transition in CNS trauma: cause or effect of neuronal cell death? J. Neurosci. Res., 2005, 79(1-2), 231239. [http://dx.doi.org/10.1002/jnr.20292] [PMID: 15573402]

[49] Jacquard, C.; Trioulier, Y.; Cosker, F.; Escartin, C.; Bizat, N.; Hantraye, P.; Cancela, J.M.; Bonvento, G.; Brouillet, E. Brain mitochondrial defects amplify intracellular $\left[\mathrm{Ca}^{2+}\right]$ rise and neurodegeneration but not $\mathrm{Ca} 2+$ entry during NMDA receptor activation. FASEB J., 2006, 20(7), 1021-1023. [http://dx.doi.org/10.1096/ fj.05-5085fje] [PMID: 16571773]

[50] Lewén, A.; Fujimura, M.; Sugawara, T.; Matz, P.; Copin, J-C.; Chan, P.H. Oxidative stress-dependent release of mitochondrial cytochrome c after traumatic brain injury. J. Cereb. Blood Flow Metab., 2001, 21(8), 914-920. [http://dx.doi.org/10.1097/00004647200108000-00003] [PMID: 11487726]

[51] Olney, J. Excitotoxicity: an overview. Canada diseases weekly report $=$ Rapport hebdomadaire des maladies au Canada 1990, 16, 47-57; discussion 57-8

[52] Palmer, A.M.; Marion, D.W.; Botscheller, M.L.; Redd, E.E. Therapeutic hypothermia is cytoprotective without attenuating the traumatic brain injury-induced elevations in interstitial concentrations of aspartate and glutamate. J. Neurotrauma, 1993, 10(4), 363-372. [http://dx.doi.org/10.1089/neu.1993.10.363] [PMID: 7908337]

[53] Bullock, R.; Zauner, A.; Woodward, J.J.; Myseros, J.; Choi, S.C.; Ward, J.D.; Marmarou, A.; Young, H.F. Factors affecting excitatory amino acid release following severe human head injury. $J$. Neurosurg., 1998, 89(4), 507-518. [http://dx.doi.org/10.3171/jns. 1998.89.4.0507] [PMID: 9761042]

[54] Robertson, C.L.; Bell, M.J.; Kochanek, P.M.; Adelson, P.D.; Ruppel, R.A.; Carcillo, J.A.; Wisniewski, S.R.; Mi, Z.; Janesko, K.L.; Clark, R.S.; Marion, D.W.; Graham, S.H.; Jackson, E.K. Increased adenosine in cerebrospinal fluid after severe traumatic brain injury in infants and children: association with severity of injury and excitotoxicity. Crit. Care Med., 2001, 29(12), 2287-2293. [http://dx. doi.org/10.1097/00003246-200112000-00009] [PMID: 11801827]

[55] Nishizawa, Y. Glutamate release and neuronal damage in ischemia. Life Sci., 2001, 69(4), 369-381. [http://dx.doi.org/10.1016/S00243205(01)01142-0] [PMID: 11459428]

[56] Floyd, C.L.; Gorin, F.A.; Lyeth, B.G. Mechanical strain injury increases intracellular sodium and reverses $\mathrm{Na}^{+} / \mathrm{Ca}^{2+}$ exchange in cortical astrocytes. Glia, 2005, 51(1), 35-46. [http://dx.doi.org/ 10.1002/glia.20183] [PMID: 15779085]

[57] Yi, J-H.; Hazell, A.S. Excitotoxic mechanisms and the role of astrocytic glutamate transporters in traumatic brain injury. Neurochem. Int., 2006, 48(5), 394-403. [http://dx.doi.org/10.1016/j. neuint.2005.12.001] [PMID: 16473439]

[58] Obrenovitch, T.P.; Urenjak, J. Is high extracellular glutamate the key to excitotoxicity in traumatic brain injury? J. Neurotrauma, 1997, 14(10), 677-698. [http://dx.doi.org/10.1089/neu.1997.14.677] [PMID: 9383088] 
[59] Bayir, H.; Kagan, V.E.; Borisenko, G.G.; Tyurina, Y.Y.; Janesko, K.L.; Vagni, V.A.; Billiar, T.R.; Williams, D.L.; Kochanek, P.M. Enhanced oxidative stress in iNOS-deficient mice after traumatic brain injury: support for a neuroprotective role of iNOS. J. Cereb. Blood Flow Metab., 2005, 25(6), 673-684. [http://dx.doi.org/ 10.1038/sj.jcbfm.9600068] [PMID: 15716856]

[60] Chong, Z.Z.; Li, F.; Maiese, K. Oxidative stress in the brain: novel cellular targets that govern survival during neurodegenerative disease. Prog. Neurobiol., 2005, 75(3), 207-246. [http://dx.doi.org/ 10.1016/j.pneurobio.2005.02.004] [PMID: 15882775]

[61] Shao, C.; Roberts, K.N.; Markesbery, W.R.; Scheff, S.W.; Lovell, M.A. Oxidative stress in head trauma in aging. Free Radic. Biol. Med., 2006, 4l(1), 77-85. [http://dx.doi.org/10.1016/j.freeradbiomed. 2006.03.007] [PMID: 16781455]

[62] Prins, M.; Greco, T.; Alexander, D.; Giza, C.C. The pathophysiology of traumatic brain injury at a glance. Dis. Model. Mech., 2013, 6(6), 1307-1315. [http://dx.doi.org/10.1242/dmm.011585] [PMID: 24046353]

[63] Lewén, A.; Matz, P.; Chan, P.H. Free radical pathways in CNS injury. J. Neurotrauma, 2000, 17(10), 871-890. [http://dx.doi. org/10.1089/neu.2000.17.871] [PMID: 11063054]

[64] Kontos, H.A.; Wei, E.P. Superoxide production in experimental brain injury. J. Neurosurg., 1986, 64(5), 803-807. [http://dx.doi. org/10.3171/jns.1986.64.5.0803] [PMID: 3009736]

[65] Chaudière, J.; Ferrari-Iliou, R. Intracellular antioxidants: from chemical to biochemical mechanisms. Food Chem. Toxicol., 1999, 37(9-10), 949-962. [http://dx.doi.org/10.1016/S0278-6915(99) 00090-3] [PMID: 10541450]

[66] Love, S. Oxidative stress in brain ischemia. Brain Pathol., 1999, 9(1), 119-131. [http://dx.doi.org/10.1111/j.1750-3639.1999.tb00214. x] [PMID: 9989455]

[67] Keynes, R.G.; Garthwaite, J. Nitric oxide and its role in ischaemic brain injury. Curr. Mol. Med., 2004, 4(2), 179-191. [http://dx. doi.org/10.2174/1566524043479176] [PMID: 15032712]

[68] Calabrese, V.; Mancuso, C.; Calvani, M.; Rizzarelli, E.; Butterfield, D.A.; Stella, A.M.G. Nitric oxide in the central nervous system: neuroprotection versus neurotoxicity. Nat. Rev. Neurosci., 2007, 8(10), 766-775. [http://dx.doi.org/10.1038/nrn2214] [PMID: 17882254]

[69] Enevoldsen, E.M.; Jensen, F.T. Autoregulation and $\mathrm{CO}_{2}$ responses of cerebral blood flow in patients with acute severe head injury. J. Neurosurg., 1978, 48(5), 689-703. [http://dx.doi.org/10.3171/ jns.1978.48.5.0689] [PMID: 641549]

[70] Hauerberg, J.; Xiaodong, M.; Willumsen, L.; Pedersen, D.B.; Juhler, M. The upper limit of cerebral blood flow autoregulation in acute intracranial hypertension. J. Neurosurg. Anesthesiol., 1998, 10(2), 106-112. [http://dx.doi.org/10.1097/00008506-19980400000007] [PMID: 9559769]

[71] Hlatky, R.; Furuya, Y.; Valadka, A.B.; Gonzalez, J.; Chacko, A.; Mizutani, Y.; Contant, C.F.; Robertson, C.S. Dynamic autoregulatory response after severe head injury. J. Neurosurg., 2002, 97(5), 1054-1061. [http://dx.doi.org/10.3171/jns.2002.97.5.1054] [PMID: $12450026]$

[72] Jaeger, M.; Schuhmann, M.U.; Soehle, M.; Meixensberger, J. Continuous assessment of cerebrovascular autoregulation after traumatic brain injury using brain tissue oxygen pressure reactivity. Crit. Care Med., 2006, 34(6), 1783-1788. [http://dx.doi.org/10. 1097/01.CCM.0000218413.51546.9E] [PMID: 16625135]

[73] Jünger, E.C.; Newell, D.W.; Grant, G.A.; Avellino, A.M.; Ghatan, S.; Douville, C.M.; Lam, A.M.; Aaslid, R.; Winn, H.R. Cerebral autoregulation following minor head injury. J. Neurosurg., 1997, 86(3), 425-432. [http://dx.doi.org/10.3171/jns.1997.86.3.0425] [PMID: 9046298]

[74] Lam, J.M.; Hsiang, J.N.; Poon, W.S. Monitoring of autoregulation using laser Doppler flowmetry in patients with head injury. $\mathrm{J}$. Neurosurg., 1997, 86(3), 438-445. [http://dx.doi.org/10.3171/jns. 1997.86.3.0438] [PMID: 9046300]

[75] Chesnut, R.M.; Marshall, L.F.; Klauber, M.R.; Blunt, B.A.; Baldwin, N.; Eisenberg, H.M.; Jane, J.A.; Marmarou, A.; Foulkes, M.A. The role of secondary brain injury in determining outcome from severe head injury. J. Trauma, 1993, 34(2), 216-222. [http:// dx.doi.org/10.1097/00005373-199302000-00006] [PMID: 8459458] Lee, J.H.; Kelly, D.F.; Oertel, M.; McArthur, D.L.; Glenn, T.C.; Vespa, P.; Boscardin, W.J.; Martin, N.A. Carbon dioxide reactivity, pressure autoregulation, and metabolic suppression reactivity after head injury: a transcranial Doppler study. J. Neurosurg., 2001, 95(2), 222-232. [http://dx.doi.org/10.3171/jns.2001.95.2.0222] [PMID: 11780891]

[77] McLaughlin, M.R.; Marion, D.W. Cerebral blood flow and vasoresponsivity within and around cerebral contusions. J. Neurosurg., 1996, 85(5), 871-876. [http://dx.doi.org/10.3171/jns.1996.85. 5.0871] [PMID: 8893726]

[78] Cunningham, A.S.; Salvador, R.; Coles, J.P.; Chatfield, D.A.; Bradley, P.G.; Johnston, A.J.; Steiner, L.A.; Fryer, T.D.; Aigbirhio, F.I.; Smielewski, P.; Williams, G.B.; Carpenter, T.A.; Gillard, J.H.; Pickard, J.D.; Menon, D.K. Physiological thresholds for irreversible tissue damage in contusional regions following traumatic brain injury. Brain, 2005, 128(Pt 8), 1931-1942. [http://dx.doi.org/10. 1093/brain/awh536] [PMID: 15888537]

[79] Clark, R.S.; Carcillo, J.A.; Kochanek, P.M.; Obrist, W.D.; Jackson, E.K.; Mi, Z.; Wisneiwski, S.R.; Bell, M.J.; Marion, D.W. Cerebrospinal fluid adenosine concentration and uncoupling of cerebral blood flow and oxidative metabolism after severe head injury in humans. Neurosurgery, 1997, 41(6), 1284-1292. [http://dx.doi.org/ 10.1097/00006123-199712000-00010] [PMID: 9402580]

[80] Diringer, M.N.; Yundt, K.; Videen, T.O.; Adams, R.E.; Zazulia, A.R.; Deibert, E.; Aiyagari, V.; Dacey, R.G., Jr; Grubb, R.L., Jr; Powers, W.J. No reduction in cerebral metabolism as a result of early moderate hyperventilation following severe traumatic brain injury. J. Neurosurg., 2000, 92(1), 7-13. [http://dx.doi.org/10.3171/ jns.2000.92.1.0007] [PMID: 10616076]

[81] Wu, H-M.; Huang, S-C.; Hattori, N.; Glenn, T.C.; Vespa, P.M.; Yu, C-L.; Hovda, D.A.; Phelps, M.E.; Bergsneider, M. Selective metabolic reduction in gray matter acutely following human traumatic brain injury. J. Neurotrauma, 2004, 21(2), 149-161. [http:// dx.doi.org/10.1089/089771504322778613] [PMID: 15000756]

[82] Tavazzi, B.; Signoretti, S.; Lazzarino, G.; Amorini, A.M.; Delfini, R.; Cimatti, M.; Marmarou, A.; Vagnozzi, R. Cerebral oxidative stress and depression of energy metabolism correlate with severity of diffuse brain injury in rats. Neurosurgery, 2005, 56(3), 582-589. [http://dx.doi.org/10.1227/01.NEU.0000156715.04900.E6] [PMID: 15730584]

[83] Verweij, B.H.; Muizelaar, J.P.; Vinas, F.C.; Peterson, P.L.; Xiong, Y.; Lee, C.P. Impaired cerebral mitochondrial function after traumatic brain injury in humans. J. Neurosurg., 2000, 93(5), 815-820. [http://dx.doi.org/10.3171/jns.2000.93.5.0815] [PMID: 11059663]

[84] Magnoni, S.; Ghisoni, L.; Locatelli, M.; Caimi, M.; Colombo, A.; Valeriani, V.; Stocchetti, N. Lack of improvement in cerebral metabolism after hyperoxia in severe head injury: a microdialysis study. J. Neurosurg., 2003, 98(5), 952-958. [http://dx.doi.org/ 10.3171/jns.2003.98.5.0952] [PMID: 12744353]

[85] Bergsneider, M.; Hovda, D.A.; Shalmon, E.; Kelly, D.F.; Vespa, P.M.; Martin, N.A.; Phelps, M.E.; McArthur, D.L.; Caron, M.J.; Kraus, J.F.; Becker, D.P. Cerebral hyperglycolysis following severe traumatic brain injury in humans: a positron emission tomography study. J. Neurosurg., 1997, 86(2), 241-251. [http://dx.doi. org/10.3171/jns.1997.86.2.0241] [PMID: 9010426]

[86] Chen, S-F.; Richards, H.K.; Smielewski, P.; Johnström, P.; Salvador, R.; Pickard, J.D.; Harris, N.G. Relationship between flowmetabolism uncoupling and evolving axonal injury after experimental traumatic brain injury. J. Cereb. Blood Flow Metab., 2004, 24(9), 1025-1036. [http://dx.doi.org/10.1097/01.WCB.0000129415. 34520.47] [PMID: 15356423]

[87] Glenn, T.C.; Kelly, D.F.; Boscardin, W.J.; McArthur, D.L.; Vespa, P.; Oertel, M.; Hovda, D.A.; Bergsneider, M.; Hillered, L.; Martin, N.A. Energy dysfunction as a predictor of outcome after moderate or severe head injury: indices of oxygen, glucose, and lactate metabolism. J. Cereb. Blood Flow Metab., 2003, 23(10), 1239-1250 [http://dx.doi.org/10.1097/01.WCB.0000089833.23606.7F] [PMID: 14526234]

[88] Greve, M.W.; Zink, B.J. Pathophysiology of traumatic brain injury. Mt. Sinai J. Med., 2009, 76(2), 97-104. [http://dx.doi.org/10.1002/ msj.20104] [PMID: 19306379]

[89] Wang, T.; Huang, X-J.; Van, K.C.; Went, G.T.; Nguyen, J.T.; Lyeth, B.G. Amantadine improves cognitive outcome and increases neuronal survival after fluid percussion traumatic brain injury in rats. J. Neurotrauma, 2014, 31(4), 370-377. [http://dx.doi.org/10 1089/neu.2013.2917] [PMID: 23574258]

[90] Hinzman, J.M.; Thomas, T.C.; Quintero, J.E.; Gerhardt, G.A.; Lifshitz, J. Disruptions in the regulation of extracellular glutamate 
by neurons and glia in the rat striatum two days after diffuse brain injury. J. Neurotrauma, 2012, 29(6), 1197-1208. [http://dx.doi. org/10.1089/neu.2011.2261] [PMID: 22233432]

[91] Mellergård, P.; Sjögren, F.; Hillman, J. The cerebral extracellular release of glycerol, glutamate, and FGF2 is increased in older patients following severe traumatic brain injury. J. Neurotrauma, 2012, 29(1), 112-118. [http://dx.doi.org/10.1089/neu.2010.1732] [PMID: 21988111]

[92] Kim, J.P.; Choi, D.W. Quinolinate neurotoxicity in cortical cell culture. Neuroscience, 1987, 23(2), 423-432. [http://dx.doi.org/10. 1016/0306-4522(87)90066-2] [PMID: 2963969]

[93] Johnston, A.J.; Steiner, L.A.; Coles, J.P.; Chatfield, D.A.; Fryer, T.D.; Smielewski, P.; Hutchinson, P.J.; O’Connell, M.T.; Al-Rawi, P.G.; Aigbirihio, F.I.; Clark, J.C.; Pickard, J.D.; Gupta, A.K.; Menon, D.K. Effect of cerebral perfusion pressure augmentation on regional oxygenation and metabolism after head injury. Crit. Care Med., 2005, 33(1), 189-195. [http://dx.doi.org/10.1097/01.CCM. 0000149837.09225.BD] [PMID: 15644668]

[94] Rose, J.C.; Neill, T.A.; Hemphill, J.C. III Continuous monitoring of the microcirculation in neurocritical care: an update on brain tissue oxygenation. Curr. Opin. Crit. Care, 2006, 12(2), 97-102. [http://dx.doi.org/10.1097/01.ccx.0000216574.26686.e9] [PMID: 16543783]

[95] Lang, E.W.; Czosnyka, M.; Mehdorn, H.M. Tissue oxygen reactivity and cerebral autoregulation after severe traumatic brain injury. Crit. Care Med., 2003, 31(1), 267-271. [http://dx.doi.org/10.1097/ 00003246-200301000-00042] [PMID: 12545027]

[96] Stiefel, M.F.; Udoetuk, J.D.; Spiotta, A.M.; Gracias, V.H.; Goldberg, A.; Maloney-Wilensky, E.; Bloom, S.; Le Roux, P.D. Conventional neurocritical care and cerebral oxygenation after traumatic brain injury. J. Neurosurg., 2006, 105(4), 568-575. [http:// dx.doi.org/10.3171/jns.2006.105.4.568] [PMID: 17044560]

[97] Leal-Noval, S.R.; Rincón-Ferrari, M.D.; Marin-Niebla, A.; Cayuela, A.; Arellano-Orden, V.; Marín-Caballos, A.; Amaya-Villar, R.; Ferrándiz-Millón, C.; Murillo-Cabeza, F. Transfusion of erythrocyte concentrates produces a variable increment on cerebral oxygenation in patients with severe traumatic brain injury: a preliminary study. Intensive Care Med., 2006, 32(11), 1733-1740. [http:// dx.doi.org/10.1007/s00134-006-0376-2] [PMID: 17019549]

[98] Stiefel, M.F.; Spiotta, A.; Gracias, V.H.; Garuffe, A.M.; Guillamondegui, O.; Maloney-Wilensky, E.; Bloom, S.; Grady, M.S.; LeRoux, P.D. Reduced mortality rate in patients with severe traumatic brain injury treated with brain tissue oxygen monitoring. $J$. Neurosurg., 2005, 103(5), 805-811. [http://dx.doi.org/10.3171/ jns.2005.103.5.0805] [PMID: 16304983]

[99] Das, M.; Leonardo, C.C.; Rangooni, S.; Pennypacker, K.R.; Mohapatra, S.; Mohapatra, S.S. Lateral fluid percussion injury of the brain induces CCL20 inflammatory chemokine expression in rats. J. Neuroinflammation, 2011, 8(1), 148. [http://dx.doi.org/10.1186/ 1742-2094-8-148] [PMID: 22040257]

[100] Streit, W.J. Microglia as neuroprotective, immunocompetent cells of the CNS. Glia, 2002, 40(2), 133-139. [http://dx.doi.org/10.1002/ glia.10154] [PMID: 12379901]

[101] Bye, N.; Habgood, M.D.; Callaway, J.K.; Malakooti, N.; Potter, A.; Kossmann, T.; Morganti-Kossmann, M.C. Transient neuroprotection by minocycline following traumatic brain injury is associated with attenuated microglial activation but no changes in cell apoptosis or neutrophil infiltration. Exp. Neurol., 2007, 204(1), 220-233. [http:// dx.doi.org/10.1016/j.expneurol.2006.10.013] [PMID: 17188268]

[102] Lopes, R.S.; Cardoso, M.M.; Sampaio, A.O.; Barbosa, M.S., Jr; Souza, C.C.; DA Silva, M.C.; Ferreira, E.M.N.; Freire, M.A.M.; Lima, R.R.; Gomes-Leal, W. Indomethacin treatment reduces microglia activation and increases numbers of neuroblasts in the subventricular zone and ischaemic striatum after focal ischaemia. $J$. Biosci., 2016, 41(3), 381-394. [http://dx.doi.org/10.1007/s12038016-9621-1] [PMID: 27581930]

[103] Guimarães, J.S.; Freire, M.A.M.; Lima, R.R.; Picanço-Diniz, C.W.; Pereira, A.; Gomes-Leal, W. Minocycline treatment reduces white matter damage after excitotoxic striatal injury. Brain Res., 2010, 1329, 182-193. [http://dx.doi.org/10.1016/j.brainres.2010.03.007] [PMID: 20226770]

[104] Lucas, S.M.; Rothwell, N.J.; Gibson, R.M. The role of inflammation in CNS injury and disease. Br. J. Pharmacol., 2006, 147(S1)(Suppl. 1), S232-S240. [http://dx.doi.org/10.1038/sj.bjp. 0706400] [PMID: 16402109]
[105] Potts, M.B.; Koh, S-E.; Whetstone, W.D.; Walker, B.A.; Yoneyama, T.; Claus, C.P.; Manvelyan, H.M.; Noble-Haeusslein, L.J. Traumatic injury to the immature brain: inflammation, oxidative injury, and iron-mediated damage as potential therapeutic targets. NeuroRx, 2006, 3(2), 143-153. [http://dx.doi.org/10.1016/j.nurx. 2006.01.006] [PMID: 16554253]

[106] Zhang, Z.; Artelt, M.; Burnet, M.; Trautmann, K.; Schluesener, H.J. Early infiltration of CD8+ macrophages/microglia to lesions of rat traumatic brain injury. Neuroscience, 2006, 141(2), 637-644. [http:// dx.doi.org/10.1016/j.neuroscience.2006.04.027] [PMID: 16725271]

[107] Fabricius, M.; Fuhr, S.; Bhatia, R.; Boutelle, M.; Hashemi, P.; Strong, A.J.; Lauritzen, M. Cortical spreading depression and periinfarct depolarization in acutely injured human cerebral cortex. Brain, 2006, 129(Pt 3), 778-790. [http://dx.doi.org/10.1093/ brain/awh716] [PMID: 16364954]

[108] Lee, J.H.; Martin, N.A.; Alsina, G.; McArthur, D.L.; Zaucha, K.; Hovda, D.A.; Becker, D.P. Hemodynamically significant cerebral vasospasm and outcome after head injury: a prospective study. $J$. Neurosurg., 1997, 87(2), 221-233. [http://dx.doi.org/10.3171/jns. 1997.87.2.0221] [PMID: 9254085]

[109] Oertel, M.; Boscardin, W.J.; Obrist, W.D.; Glenn, T.C.; McArthur, D.L.; Gravori, T.; Lee, J.H.; Martin, N.A. Posttraumatic vasospasm: the epidemiology, severity, and time course of an underestimated phenomenon: a prospective study performed in 299 patients. J. Neurosurg., 2005, 103(5), 812-824. [http://dx.doi.org/10. 3171/jns.2005.103.5.0812] [PMID: 16304984]

[110] Sobey, C.G. Cerebrovascular dysfunction after subarachnoid haemorrhage: novel mechanisms and directions for therapy. Clin. Exp. Pharmacol. Physiol., 2001, 28(11), 926-929. [http://dx.doi. org/10.1046/j.1440-1681.2001.03550.x] [PMID: 11703398]

[111] Zuccarello, M.; Boccaletti, R.; Romano, A.; Rapoport, R.M. Endothelin B receptor antagonists attenuate subarachnoid hemorrhageinduced cerebral vasospasm. Stroke, 1998, 29(9), 1924-1929. [http://dx.doi.org/10.1161/01.STR.29.9.1924] [PMID: 9731620]

[112] Todo, H.; Ohta, S.; Wang, J.; Ichikawa, H.; Ohue, S.; Kumon, Y.; Sakaki, S. Impairment in biochemical level of arterial dilative capability of a cyclic nucleotides-dependent pathway by induced vasospasm in the canine basilar artery. J. Cereb. Blood Flow Metab., 1998, 18(7), 808-817. [http://dx.doi.org/10.1097/00004647199807000-00011] [PMID: 9663510]

[113] Armstead, W.M. Differential activation of ERK, p38, and JNK MAPK by nociceptin/orphanin FQ in the potentiation of prostaglandin cerebrovasoconstriction after brain injury. Eur. J. Pharmacol., 2006, 529(1-3), 129-135. [http://dx.doi.org/10.1016/j.ejphar. 2005.08.059] [PMID: 16352304]

[114] Eldadah, B.A.; Faden, A.I. Caspase pathways, neuronal apoptosis, and CNS injury. J. Neurotrauma, 2000, 17(10), 811-829. [http:// dx.doi.org/10.1089/neu.2000.17.811] [PMID: 11063050]

[115] Nathoo, N.; Narotam, P.K.; Agrawal, D.K.; Connolly, C.A.; van Dellen, J.R.; Barnett, G.H.; Chetty, R. Influence of apoptosis on neurological outcome following traumatic cerebral contusion. $J$. Neurosurg., 2004, 101(2), 233-240. [http://dx.doi.org/10.3171/jns. 2004.101.2.0233] [PMID: 15309913]

[116] Uzan, M.; Erman, H.; Tanriverdi, T.; Sanus, G.Z.; Kafadar, A.; Uzun, H. Evaluation of apoptosis in cerebrospinal fluid of patients with severe head injury. Acta Neurochir. (Wien), 2006, 148(11), 1157-1164. [http://dx.doi.org/10.1007/s00701-006-0887-1] [PMID: 16964558]

[117] Liu, X.Z.; Xu, X.M.; Hu, R.; Du, C.; Zhang, S.X.; McDonald, J.W.; Dong, H.X.; Wu, Y.J.; Fan, G.S.; Jacquin, M.F.; Hsu, C.Y.; Choi, D.W. Neuronal and glial apoptosis after traumatic spinal cord injury. J. Neurosci., 1997, 17(14), 5395-5406. [http://dx.doi.org/ 10.1523/JNEUROSCI.17-14-05395.1997] [PMID: 9204923]

[118] Choi, D.W. Ischemia-induced neuronal apoptosis. Curr. Opin. Neurobiol., 1996, 6(5), 667-672. [http://dx.doi.org/10.1016/S09594388(96)80101-2] [PMID: 8937832]

[119] Algattas, H.; Huang, J.H. Traumatic Brain Injury pathophysiology and treatments: early, intermediate, and late phases post-injury. Int. J. Mol. Sci., 2013, 15(1), 309-341. [http://dx.doi.org/10.3390/ijms 15010309] [PMID: 24381049]

[120] Yoshino, A.; Hovda, D.A.; Kawamata, T.; Katayama, Y.; Becker, D.P. Dynamic changes in local cerebral glucose utilization following cerebral conclusion in rats: evidence of a hyper- and subsequent hypometabolic state. Brain Res., 1991, 561(1), 106-119. [http:// dx.doi.org/10.1016/0006-8993(91)90755-K] [PMID: 1797338] 
[121] Madikians, A.; Giza, C.C. A clinician's guide to the pathophysiology of traumatic brain injury. Indian J Neurotrauma, 2006, 3(1), 917. [http://dx.doi.org/10.1016/S0973-0508(06)80004-3]

[122] Bergsneider, M.; Hovda, D.A.; Lee, S.M.; Kelly, D.F.; McArthur, D.L.; Vespa, P.M.; Lee, J.H.; Huang, S.C.; Martin, N.A.; Phelps, M.E.; Becker, D.P. Dissociation of cerebral glucose metabolism and level of consciousness during the period of metabolic depression following human traumatic brain injury. J. Neurotrauma, 2000, 17(5), 389-401. [http://dx.doi.org/10.1089/neu.2000.17.389] [PMID: 10833058]

[123] Biros, M.H.; Dimlich, R.V. Brain lactate during partial global ischemia and reperfusion: effect of pretreatment with dichloroacetate in a rat model. Am. J. Emerg. Med., 1987, 5(4), 271-277. [http:// dx.doi.org/10.1016/0735-6757(87)90349-4] [PMID: 3593491]

[124] Nilsson, B.; Nordström, C-H. Rate of cerebral energy consumption in concussive head injury in the rat. J. Neurosurg., 1977, 47(2), 274-281. [http://dx.doi.org/10.3171/jns.1977.47.2.0274] [PMID: 874550]

[125] Siemkowicz, E.; Hansen, A.J. Clinical restitution following cerebral ischemia in hypo-, normo- and hyperglycemic rats. Acta Neurol. Scand., 1978, 58(1), 1-8. [http://dx.doi.org/10.1111/j.16000404.1978.tb02855.x] [PMID: 30250]

[126] Doberstein, C.E.; Hovda, D.A.; Becker, D.P. Clinical considerations in the reduction of secondary brain injury. Ann. Emerg. Med., 1993, 22(6), 993-997. [http://dx.doi.org/10.1016/S0196-0644(05) 82740-4] [PMID: 8503538]

[127] Yang, M.S.; DeWitt, D.S.; Becker, D.P.; Hayes, R.L. Regional brain metabolite levels following mild experimental head injury in the cat. J. Neurosurg., 1985, 63(4), 617-621. [http://dx.doi.org/ 10.3171/jns.1985.63.4.0617] [PMID: 4032026]

[128] Inao, S.; Marmarou, A.; Clarke, G.D.; Andersen, B.J.; Fatouros, P.P.; Young, H.F. Production and clearance of lactate from brain tissue, cerebrospinal fluid, and serum following experimental brain injury. J. Neurosurg., 1988, 69(5), 736-744. [http://dx.doi.org/ 10.3171/jns.1988.69.5.0736] [PMID: 3183734]

[129] Bramlett, H.M.; Dietrich, W.D. Pathophysiology of cerebral ischemia and brain trauma: similarities and differences. J. Cereb. Blood Flow Metab., 2004, 24(2), 133-150. [http://dx.doi.org/10. 1097/01.WCB.0000111614.19196.04] [PMID: 14747740]

[130] Martin, N.A.; Patwardhan, R.V.; Alexander, M.J.; Africk, C.Z.; Lee, J.H.; Shalmon, E.; Hovda, D.A.; Becker, D.P. Characterization of cerebral hemodynamic phases following severe head trauma: hypoperfusion, hyperemia, and vasospasm. J. Neurosurg., 1997, 87(1), 9-19. [http://dx.doi.org/10.3171/jns.1997.87.1.0009] [PMID: 9202259]

[131] Rodríguez-Baeza, A.; Reina-de la Torre, F.; Poca, A.; Martí, M.; Garnacho, A. Morphological features in human cortical brain microvessels after head injury: a three-dimensional and immunocytochemical study. Anat. Rec. A Discov. Mol. Cell. Evol. Biol., 2003, 273(1), 583-593. [http://dx.doi.org/10.1002/ar.a.10069] [PMID: 12808643

[132] Kelly, D.F.; Martin, N.A.; Kordestani, R.; Counelis, G.; Hovda, D.A.; Bergsneider, M.; McBride, D.Q.; Shalmon, E.; Herman, D.; Becker, D.P. Cerebral blood flow as a predictor of outcome following traumatic brain injury. J. Neurosurg., 1997, 86(4), 633-641. [http://dx.doi.org/10.3171/jns.1997.86.4.0633] [PMID: 9120627]
[133] Kelly, D.F.; Kordestani, R.K.; Martin, N.A.; Nguyen, T.; Hovda, D.A.; Bergsneider, M.; McArthur, D.L.; Becker, D.P. Hyperemia following traumatic brain injury: relationship to intracranial hypertension and outcome. J. Neurosurg., 1996, 85(5), 762-771. [http:// dx.doi.org/10.3171/jns.1996.85.5.0762] [PMID: 8893712]

[134] Bouma, G.J.; Muizelaar, J.P. Cerebral blood flow, cerebral blood volume, and cerebrovascular reactivity after severe head injury. $J$. Neurotrauma, 1992, 9(Suppl. 1), S333-S348. [PMID: 1588625]

[135] Mazzini, L.; Campini, R.; Angelino, E.; Rognone, F.; Pastore, I.; Oliveri, G. Posttraumatic hydrocephalus: a clinical, neuroradiologic, and neuropsychologic assessment of long-term outcome. Arch. Phys. Med. Rehabil., 2003, 84(11), 1637-1641. [http://dx. doi.org/10.1053/S0003-9993(03)00314-9] [PMID: 14639563]

[136] Katz, R.T.; Brander, V.; Sahgal, V. Updates on the diagnosis and management of posttraumatic hydrocephalus. Am. J. Phys. Med. Rehabil., 1989, 68(2), 91-96. [http://dx.doi.org/10.1097/00002060198904000-00009] [PMID: 2649117]

[137] Groswasser, Z.; Cohen, M.; Reider-Groswasser, I.; Stern, M.J. Incidence, CT findings and rehabilitation outcome of patients with communicative hydrocephalus following severe head injury. Brain Inj., 1988, 2(4), 267-272. [http://dx.doi.org/10.3109/ 02699058809150897] [PMID: 3203174]

[138] Portnoy, H.D.; Chopp, M.; Branch, C.; Shannon, M.B. Cerebrospinal fluid pulse waveform as an indicator of cerebral autoregulation J. Neurosurg., 1982, 56(5), 666-678. [http://dx.doi.org/10.3171/jns. 1982.56.5.0666] [PMID: 7069479]

[139] Factora, R.; Luciano, M. Normal pressure hydrocephalus: diagnosis and new approaches to treatment. Clin. Geriatr. Med., 2006, 22(3), 645 657. [http://dx.doi.org/10.1016/j.cger.2006.05.001] [PMID: 16860251]

[140] Mori, K.; Shimada, J.; Kurisaka, M.; Sato, K.; Watanabe, K. Classification of hydrocephalus and outcome of treatment. Brain Dev. 1995, 17(5), 338-348. [http://dx.doi.org/10.1016/0387-7604(95) 00070-R] [PMID: 8579221]

[141] Kammersgaard, L.P.; Linnemann, M.; Tibæk, M. Hydrocephalus following severe traumatic brain injury in adults. Incidence, timing, and clinical predictors during rehabilitation. NeuroRehabilitation, 2013, 33(3), 473-480. [PMID: 23949078]

[142] Linnemann, M.; Tibæk, M.; Kammersgaard, L.P. Hydrocephalus during rehabilitation following severe TBI. Relation to recovery, outcome, and length of stay. NeuroRehabilitation, 2014, 35(4), 755-761. [PMID: 25318768]

[143] Rehman, T.; Ali, R.; Tawil, I.; Yonas, H. Rapid progression of traumatic bifrontal contusions to transtentorial herniation: A case report. Cases J., 2008, l(1), 203. [http://dx.doi.org/10.1186/17571626-1-203] [PMID: 18831756]

[144] Dawodu, S. T. Traumatic brain injury: definition, epidemiology, pathophysiology. E medicine from WebMD 2007.

[145] Packet, S-L. Overview of adult traumatic brain injuries; Orlando Regional Healthcare, Education \& Development: Orlando, FL, 2004.

[146] Freeman, M.D.; Rosa, S.; Harshfield, D.; Smith, F.; Bennett, R.; Centeno, C.J.; Kornel, E.; Nystrom, A.; Heffez, D.; Kohles, S.S. A case-control study of cerebellar tonsillar ectopia (Chiari) and head/ neck trauma (whiplash). Brain Inj., 2010, 24(7-8), 988-994. [http:// dx.doi.org/10.3109/02699052.2010.490512] [PMID: 20545453] 